\title{
Cutting Corners or Enhancing Efficiency?
}

\author{
Simplified Procedures and the Israeli Quest to Speed up Justice
}

\author{
Ehud Brosh*
}

\begin{abstract}
Israel was spared the worst of the world financial crisis of 2008-2009. However, austerity concerns are by no means invisible in the developments in the field of civil procedure. These concerns correlate heavily with the long-standing Israeli preoccupation with 'speeding up' justice. An array of simplified procedural tracks, aimed at addressing the perceived inadequacy of 'standard' procedure, have been developed in Israel over the years. The importance of simplified procedures in the Israeli system cannot be overestimated. Their development illustrates the dialectical tension between the values of 'efficiency' and 'quality' in the administration of justice. During periods of austerity, the scales are easily (or easier) tipped in favour of efficiency and general or particular simplification of procedure. In times of prosperity, on the other hand, concerns over 'quality', access to justice, and truth discovery predominate, and attempts at promoting efficiency and/or simplification at their expense tend to be bogged down. Such attempts also tend to lose their extrinsic legitimacy and are widely viewed as 'cutting corners'. This is evident in the recent Israeli experience with civil procedure reform.
\end{abstract}

Keywords: Israel, austerity, civil procedure, simplified procedures, small claims

\section{Introduction}

'Austerity seems to loom over everything nowadays, and procedure is not exempt. ${ }^{1}$ So mused - rather wistfully - Richard Marcus in a 2013 article, while at the same time remarking that 'invoking a general fiscal crisis as a reason for making big changes in procedure seems far fetched', as '[t]he welfare state is not usually thought to include civil litigation or the way it is handled by the courts'. ${ }^{2}$ The apparent contradiction contained in these assessments has been recently resolved, in a symbolic and resounding manner, in the Euro Summit statement on the Greece bailout. The statement listed, among other preconditions for continued financial support, 'the

Ehud Brosh, LL.M., is a research student at the Hebrew University of Jerusalem.

1. R. Marcus, 'Procedure in a Time of Austerity', 3 International Journal of Procedural Law 133, at 157 (2013).

2. Id., at 137 adoption [by Greece] of the Code of Civil Procedure, which is a major overhaul of procedures and arrangements for the civil justice system and can significantly accelerate the judicial process and reduce costs' ${ }^{3}$ There can, thus, be no more doubt (if there ever was any) that austerity does 'connect meaningfully to procedure'. ${ }^{4}$

Israel stands apart from most OECD member countries in that it emerged from the global financial crisis with its attendant recession, which started in 2007 and still continues to be felt in large parts of Europe, virtually unscathed $^{5}$ (although signs of an economic slowdown have appeared in 2015). ${ }^{6}$ And yet austerity concerns (in a broader sense) are by no means irrelevant to Israeli civil procedure. ${ }^{7}$ Indeed, the opposite is true: these concerns, specifically manifested in the incessant preoccu-

3. Euro Summit Statement, Brussels, 12 July 2015, SN 4070/15, full text available at: <www.consilium.europa.eu/en/press/press-releases/2015/ 07/12-euro-summit-statement-greece/>. On the proposed new code, which encountered significant opposition from both the lawyers' and the judges' unions, see N. Kanellopoulos, 'Civil Procedure Reform in Greece', Ekathimerini, 16 March 2014, available at: <www. ekathimerini.com/158631/article/ekathimerini/comment/civil-procedure -reform-in-greece>; D. Goulas, 'Greek Lawyers on Strike for 13 Days to Protest Against a Draft Bill Amending the Civil Procedure Code', 27 November 2014, available at: <www.altalex.eu/content/greek-lawyersstrike-13-days-protest-against-draft-bill-amending-civil-procedurecode>.

4. See Marcus, above n. 1, at 137. See also F. van Dijk and H. Dumbrava, 'Judiciary in Times of Scarcity: Retrenchment and Reform', 5(1) International Journal for Court Administration 1 (2013).

5. See P. Rivlin, The Israeli Economy from the Foundation of the State Through the 21st Century (2011), at 115-6; D. Rosenberg, 'The Israeli Economy: After the Financial Crisis, New Challenges', 14(1) Middle East Review of International Affairs (2010), available at: <www.gloriacenter.org/2010/03/rosenberg-2010-03-06/>; J. Braude and N. Sussmann, 'Politique monétaire non conventionnelle: l'expérience israélienne', 113 Revue d'économie financière 103, at 104, 106 (2014). Israel's economy has exhibited steady above-average growth ever since; see OECD, OECD Economic Surveys: Israel 2013 (2013), at 6, 12.

6. T. Yahav and N. Zomer, 'Israel's Economic Growth Slowing Dramatically in 2015' (17 August 2015), available at: <www.ynetnews.com/articles/ $0,7340, \mathrm{~L}-4691570,00 . \mathrm{html}$. This slowdown does not appear to be a precursor of a full-scale recession in the short term, however. According to an October 2015 estimate by Israel's Central Bureau of Statistics, Israel's GDP growth rate for that year will be $2.5 \%$, only slightly below the 2014 rate of $2.6 \%$. See N. Neumann, 'Ha-Lama's: Ha-Meshek Yitsmah ha-Shana be-2.5\% Bilvad' ['CBI: The Economy Will Grow This Year by Just 2.5\%'], Globes, 18 October 2015, available at: <www. globes.co.il/news/article.aspx?did=1001074303> (in Hebrew).

7. On austerity's broad appeal, see N. Jabko, 'The Political Appeal of Austerity', 11 Comparative European Politics 705 (2013). The Israeli economic policy has been more or less constantly guided by fiscal restraint since the end of hyperinflation in 1985 and in an even more pronounced manner since 1996. See B.-Z. Zilberfarb, 'From Boom to Bust: The Israeli Economy 1990-2003', 12 Israel Affairs 221, at 225 (2006); Rivlin, above n. 5, at 78-84. 
pation with ensuring 'speedier' and more cost-effective justice, have been a fixture - at times in the background, at times in the forefront - of the debate over the developments in the field since the 1970s. It is especially so since the beginning of this millennium, and for good reason: in the years 2001-2003 Israel experienced a period of serious economic difficulties, entailing drastic austerity measures. ${ }^{8}$ As will be shown, it is during this recessionary spell that some important reforms aimed at streamlining the civil justice system and saving costs were introduced. Importantly, the reforms concerned themselves not only with the general procedures applicable in civil cases but also, to a large extent, with various simplified alternatives to 'standard' procedure: either by upgrading the existing alternatives or by creating new ones. However, the trend manifested in broadening the scope of simplified procedures has also encountered considerable criticism which may affect the prospect of further reforms in the future. The debate has been reinvigorated lately by the proposed general overhaul of civil procedure, put forward by the Israeli Justice Ministry in December 2014, which is discussed below.

The aim of this article is to give an overview of the Israeli experience with simplified modes of civil procedure, while highlighting their role in the attempts to increase the efficiency of the justice system, as well as the influence of austerity factors on their development. Can Israel actually be seen as (almost) a poster case of such an influence? The article proceeds as follows: Section 2 starts with a brief sketch of the Israeli legal system in general and of the civil procedure in particular. A presentation of some salient features of civil litigation in Israel, such as the caseload burden, representation, costs, and legal aid, is also provided. Section 3 then discusses in detail, and in comparative perspective, the various simplified procedures available in Israel - with special attention being paid to rationales for each of them such as Small Claims Courts, summary, and fast track procedure. Section 4 touches on the dilemma inherent in (but by no means limited to) broadening the scope of simplified procedures, especially in the context of austerity - between a deep dissatisfaction with 'slow' and unreasonably expensive justice on the one hand and concern over the effects of 'cutting procedural corners' on the overall quality of justice. This dialectical contradiction is at the core of the current debate in Israel over the merits and demerits of continued simplification of civil procedure, recently rekindled by the Justice Ministry's sweeping reform proposal. Some conclusions are briefly summed up in Section 5 .

\section{Legal and Institutional Background}

\subsection{Civil Procedure in Israel - Sources and Trends}

The Israeli legal system, which is based on a wide array of sources, historically rooted in and continuously influenced by elements of both civil and common, as well as religious law, 9 is best characterised as 'mixed'10 or 'hybrid'. ${ }^{11}$ It can also be generally described as pluralistic and multicultural, ${ }^{12}$ as well as highly dynamic. ${ }^{13}$ The system's mixed nature comes to the fore in two partly conflicting trends dominating the historical development of Israeli law: that of codification on the one hand, ${ }^{14}$ and that of judicial 'hyper-activism', ${ }^{15}$ carried by a predominantly 'common lawish' jurisprudence, ${ }^{16}$ on the other. Another underlying jurisprudential trend in Israel since the $1980 \mathrm{~s}$ - and especially so after the constitutionalisation of human rights commonly referred to as Israel's 'constitutional revolution' 17 - has been the gradual rise of (substantive) values and the decline of (formal) rules. ${ }^{18}$

Civil procedure is one of the fields of Israeli law where the British roots run deepest. In fact, the current Israeli

9. See generally A.E. Platsas, 'The Enigmatic but Unique Nature of the Israeli Legal System', 15(3) Potchefstroom Electronic Law Journal 11 (2012). On the cultural struggles over the shaping of Israeli law, and especially over the place of Jewish law within the legal system, see $M$. Mautner, Law and the Culture of Israel (2011), at 31-53.

10. A. Barak, 'Shitat ha-Mishpat ha-Yisra'elit - Masorta u-Tarbuta' ['The Israeli Legal System - Its Tradition and Culture'], 40 Ha-Praklit 197, at 209 (1992) (in Hebrew); A. Barak, 'Some Reflections on the Israeli Legal System and Its Judiciary', 6.1 Electronic Journal of Comparative Law Part 3 (2002), available at: <www.ejcl.org/61/art61-1.html>.

11. Platsas, above n. 9, at 15.

12. Id., at 14

13. Id., at 29 ('The Israeli legal system is a system characterised by legal kinesis; it is not a system of legal stasis').

14. Barak (2002), above n. 10, Part 3.

15. See generally Y. Dotan, 'Judicial Accountability in Israel: The High Court of Justice and the Phenomenon of Judicial Hyperactivism', 8(4) Israel Affairs 87 (2002); E. Salzberger, 'Judicial Activism in Israel', in B. Dickson (ed.), Judicial Activism in Common Law Supreme Courts (2007) 217.

16. Barak (2002), above n. 10, Part 3.

17. See e.g. D. Kretzmer, 'New Basic Laws on Human Rights: A Mini-Revolution in Israeli Constitutional Law?' 26 Israel Law Review 238 (1992); A. Barak, 'A Constitutional Revolution: Israel's Basic Laws', 4 Constitutional Forum 83 (1992-1993); G. Sapir, 'Constitutional Revolutions: Israel as a Case-Study', 5 International Journal of Law in Context 355 (2009). The central development in this regard is the adoption in 1992 of Basic Law: Human Dignity and Liberty, SH No. 1391, at 150.

18. See Mautner, above n. 9, at 75-98; M. Mautner, 'Yeridat ha-Formalizm ve-Aliyat ha-Arakhim ba-Mishpat ha-Yisra'eli' ['The Decline of Formalism and the Rise of Values in Israeli Law'], 17 lyunei Mishpat 503 (1983) (in Hebrew). On the gradual introduction of 'standards' at the expense of 'rules' into the Israeli civil procedure, see I. Rosen-Zvi, HaHalikh ha-Ezrahi [The Civil Process] (2015), at 223-4 (in Hebrew).
8. See Zilberfarb, above n. 7, at 227-31. This recession, mainly caused by worldwide collapse in the high-tech-industry (the 'dot-com crash') coincided with - and was exacerbated by - a protracted round of largescale Israeli-Palestinian violence known as the 'Second Intifada'. 
Rules of Civil Procedure, 1984 (hereinafter - RCP), ${ }^{19}$ are based on a verbatim translation of the (now defunct) English Rules of the Supreme Court, first introduced to the local law by the British Mandatory power in 1938, and until lately only sparsely amended. ${ }^{20}$ Nevertheless, despite its conservatism and traditionally highly formal nature, Israel's law of civil procedure has not remained immune to the influences of both constitutionalisation ${ }^{21}$ and deformalisation, the last trend being in line with the developments in other jurisdictions. ${ }^{22}$ Although the Israeli jurisprudence generally views civil procedure as a balancing instrument between two conflicting goals: stability and predictability - as embodied in black letter procedural rules - vs. discovery of the truth in order to assure justice between the litigants, ${ }^{23}$ there is a marked lack of sympathy with procedural limitations on adjudicating the merits of the case. ${ }^{24}$ The Israeli Supreme Court - especially under the influence of über-activist Justice Aharon Barak, who served as its member since 1978, and as the Court's President between 1995 and 2006 - has exhibited concern that overemphasis on procedure might lead to 'purely formal tactics' adopted by the parties, impairing the court's (primary) mission of truth discovery. ${ }^{25}$ This concern is an expression of the general importance attributed by the Israeli law to the right of access to courts. ${ }^{26}$ As a consequence, wide (and seemingly ever-growing) discretion is given to the trial

19. Rules of Civil Procedure, 5744-1984, KT 4685, at 2220. The Rules are issued by the Minister of Justice upon the authority delegated in Courts Law (Consolidated Version), 5744-1984, 38 LSI 271 (1983-1984) [hereinafter - Courts Law]. The Courts Law deals with issues such as subject matter jurisdiction, composition of judges' panels, transfer of trials, and rights of appeal. See S. Goldstein et al., Civil Procedure in Israel (2013), at 20

20. See S. Goldstein, 'Forty Years of Civil Procedure', 24 Israel Law Review 789, at 789-90 (1990); Goldstein et al., above n. 19, at 19-20.

21. On the constitutional human rights influences on the Israeli civil procedure law, see S. Levin, 'Hok Yesod: Kvod ha-Adam ve-Heruto ve-Sidrei ha-Din ha-Ezrahi'im' ['Basic Law: Human Dignity and Freedom and Civil Procedure'], 42 Ha-Praklit 451 (1995) (in Hebrew); D. Menashe, 'Seder-Din Ezrahi: Megamot Merkaziyot Likrat Kinuna shel Perspektiva Hukatit' ['Civil Procedure: Principal Trends Towards the Establishment of a Constitutional Perspective'], 22 lyunei Mishpat 205 (1999) (in Hebrew); D. Schwartz, Seder Din Ezrahi: Hidushim, Tahalikhim u-Megamot [Civil Procedure: Innovations, Processes and Trends] (2007), at 36-8, 101-31 (in Hebrew).

22. On the deformalisation philosophy underlying the new French Code of Civil Procedure, adopted in 1975, see L. Cadiet, 'Introduction to French Civil Justice System and Civil Procedural Law', 28 Ritsumeikan Law Review 331, at 367-73 (2011)

23. CA 447/92 Roth v. Intercontinental Credit Corporation, 49(2) PD 102, at 115 (1995). For an overview of the aims of Israel's civil procedure as well as its underlying principles and values (such as discovery of truth, effectiveness, certainty and predictability, finality, equality, even-handedness and equality of the party, openness, autonomy, participation, and rationality), see Rosen-Zvi, above n. 18, at 31-108.

24. See Goldstein et al., above n. 19, at 81

25. CrimA 951/80 Kanir v. State of Israel, 35(3) PD 505, at 517 (1981) (per Barak J.).

26. See HCJ 2171/06 Cohen v. Chairman of the Knesset, para. 19 (29 August 2011), Nevo Legal Database (by subscription) (per Beinisch C.J.); Schwartz, above n. 21, at 105-15. On the right of access to justice in Israel in general, and in the Israeli-Palestinian context in particular, see M.M. Karayanni, 'Access to Justice Ascends to International Civil Litigation: The Case of Palestinian Plaintiffs before Israeli Courts', 33 Civil Justice Quarterly 1 (2014). judge to rectify procedural flaws. ${ }^{27}$ This, in turn, reflects a gradual retreat from the adversarial system and towards a more interventionist role of the judge. ${ }^{28}$ The latter trend looks set to persist and to intensify, even as the previously rather light-handed approach to procedure seems to be shifting in recent years, under Barak's successors at the helm of the Supreme Court. ${ }^{29}$ The shift is also prominent in the proposed draft of new Rules of Civil Procedure (hereinafter - the Draft Rules or the Draft), intended to replace the current RCP from 1984, which was recently released by the Israeli Ministry of Justice for public perusal and discussion, ${ }^{30}$ and is examined below. ${ }^{31}$

\subsection{Caseload Burden}

The Israeli court system is notoriously overburdened. A comparative study, commissioned by the Courts Administration in 2007, found Israel is placed third in terms of the caseload burden, out of seventeen countries surveyed. ${ }^{32}$ The case backlog is also huge: according to the official yearly report on the activity of the Israeli judiciary, at the end of 2013 it stood at 440,850 cases. $^{33}$ These data can easily explain the public dissatisfaction with the protracted length of judicial proceedings in Israel - exacerbated by a practice lacking continuous and concentrated trial ${ }^{34}$ - which is generally perceived as unjustified red tape. Some stark anecdotal evidence exists as to how the judges themselves view the burden, including resignations and, in one extreme case, even suicide. ${ }^{35}$ Another telling, albeit indirect, indication of the current backlog situation in Israel - (fairly) reassur-

27. Goldstein et al., above n. 19, at 96-7; U. Goren, Sugiyot be-Seder Din Ezrahi [/ssues in Civil Procedure], 11th edn. (2013), at 9-10 (in Hebrew)

28. Schwartz, above n. 21, at 38-40; Goldstein et al., above n. 19, at 25. For similar developments in French law, see Cadiet, above n. 22, at 349.

29. On the current Israeli trend towards the adoption of an 'administrative' (or 'case management') model of adjudication, see below, Section 4.

30. State of Israel, Ministry of Justice, Tyutat Takanot Seder ha-Din haEzrahi, 5775-2014 [Draft Rules of Civil Procedure, 5775-2014] (2014) (in Hebrew), available at: <http://index.justice.gov.il/Pubilcations/ Articles/Pages/Memorandum1512.aspx>.

31. Section 4.2

32. R. Sulitzeanu-Kenan, A. Reichman \& E. Vigoda-Gadot, Ha-Omes al Ma'arakhot Mishpat: Nitu'ah Hashva'ati shel 17 Medinot [The Caseload Burden on Judiciary Systems: A Comparative analysis of 17 Countries] (2007), at 12-4, 38 (in Hebrew). The burden is calculated based on the ratio between the number of cases and the number of professional judges. A slightly different methodology, taking into account lay judges, raises Israel to the second place in the judicial burden rating. Id. at 15-6.

33. State of Israel, Courts Administration, Ha-Reshut ha-Shofetet be-Yisra'el: Du'a"h Shnati 2013 [The Judicial Authority in Israel: Yearly Report 2013] (2014), at 9 (in Hebrew), available at: <http://elyon1. court.gov.il/heb/haba/dochot/doc/shnati2013.pdf> [hereinafter Yearly Report 2013]. The overall number of new cases opened in 2013 was 724,$345 ; 752,927$ cases were closed during the same year. Id. at 9 .

34. See Goldstein et al., above n. 19, at 25. The lack of continuous trial in Israel represents a major difference between Israeli and English civil procedure and is rooted in the absence of juries in the Israeli court system. Id.

35. See S. Shetreet, 'Erkei ha-Yesod shel Ma'arekhet ha-Shfita be-Yisra'el' ['Basic Values of the Justice System in Israel'], in A. Barak, R. Sokol \& O. Shaham (eds.), Sefer Or: Kovets Ma'amarim Likhvod ha-Shofet Theodor Or [Or Book: A Collection of Articles in Honor of Justice Theodor Or] (2013) 617, at 625 (in Hebrew). 
ing official statistics notwithstanding ${ }^{36}$ - can be found in the protracted legal battle waged by the Courts Administration against a freedom of information request by Israel's leading economic newspaper, which sought to obtain data on the number of pending cases before each individual District Judge and Supreme Court Justice, and on the time that has elapsed since these cases were filed. ${ }^{37}$ Attempts to address the problems of backlog and 'slow justice' over the last decade have been only partially successful. ${ }^{38}$

\subsection{Representation, Costs, and Legal Aid}

In Israel, parties in civil proceedings have a right to be represented by an attorney of their choice (with one significant exception, discussed below). ${ }^{39}$ No mandatory representation by counsel is required, including before the Supreme Court; practically, however, a layman would lack the ability to represent himself/herself effectively even in fairly simple civil cases. ${ }^{40}$ As representation is voluntary, attorney's fees are a matter of private agreement and generally not subject to judicial control, ${ }^{41}$ though non-binding recommendations on the minimum rates, issued by the Israel Bar Association, exist. $^{42}$ State-funded legal aid in civil proceedings is regulated by special legislation. ${ }^{43}$ The criteria for eligibility, based on income and assets, are rather restrictive, largely limiting free legal aid to the poor ${ }^{44}$ while special statutory provisions, without a 'means test', are available regarding national insurance benefit claims. ${ }^{45}$ The Supreme Court has on occasion expressed concern over the inadequacy of the existing system of legal aid and pondered on the necessity of expanding it beyond the existing statutory provisions. ${ }^{46}$ This inadequacy presents a serious access-to-justice problem, exacerbated by

36. According to data published by the Israeli Courts Administration, the median lifespan of a civil case now stands at 13.8 months for the Magistrates' Courts (general courts of first instance with exclusive jurisdiction of monetary claims of up to NIS 2,500,000 - c. EUR 600,000 at the current exchange rate), and at 22.7 months for the District Courts (general courts of residual jurisdictions); $4.7 \%$ of all cases before the District Courts (over 2,000 in absolute terms) are 4 years and older. See Yearly Report 2013, above n. 33, at 20, 23, 28.

37. See AdmA 3908/11 State of Israel - The Courts Administration v. The Marker Newspaper (29 September 2014), Nevo Legal Database (by subscription). Due to its special public importance, the case was decided by an enlarged panel of seven Supreme Court Justices. Even though the Courts Administration lost, it was allowed a delay until the end of 2015 to prepare the data.

38. See below, Section 4.1.

39. See below, Section 3.1.

40. Cf. generally, R. Assy, 'Revisiting the Right to Self-Representation in Civil Proceedings', 30 Civil Justice Quarterly 267 (2011).

41. See Goldstein et al., above n. 19, at 172.

42. Bar Association Rules (Recommended Minimum Fee), 5760-2000, YP 4852 , at 2558. On the non-binding nature of these Rules, see Goren, above n. 27, at 724

43. Legal Aid Law, 5732-1972, 26 LSI 115 (1971-1972); Legal Aid Regulations, 5733-1973, KT 3062, at 2048.

44. Goldstein et al., above n. 19, at 171

45. These include claims for old-age, disability and survivors' pensions, maternity benefits and child allowances, unemployment compensation etc. See National Insurance Regulations (Legal Aid), 5738-1978, KT 3895 , at 2170 . high costs of legal representation ${ }^{47}$ and elevated court filing fees. ${ }^{48}$

A special chapter in the Israeli RCP is devoted to the issue of trial costs. ${ }^{49}$ The fundamental provision, contained in Rule 511, does not enunciate any general principle imposing the costs on the losing party, but rather grants the court sweeping discretion with regard to both the allocation and the amount of costs, with only a few rather vague guidelines. ${ }^{50}$ Thus, in practice, cost awards routinely under-compensate the actual expenditures incurred during the trial, ${ }^{51}$ while in a considerable percentage of cases, the losing party is totally exempted from bearing the winner's costs. ${ }^{52}$ This situation has evoked much criticism. ${ }^{53}$ Lately, the Israeli Supreme

46. See LCA 6810/97 Ben Shoshan v. Ben Shoshan, 51(5) PD 375, at 378-9 (1997) (per J. Türkel J.); Levin, above n. 21, at 458. The Court also recognises that difficulties in obtaining state-funded legal aid constitute a 'special reason' justifying an extension of procedural time limits for the relevant party; see HCJ 1986/06 Plonit (Jane Doe) v. High Rabbinical Court, para. 13 (27 May 2008), Nevo Legal Database (by subscription) (per E. Arbel J.); LCA 9382/10 Ploni (John Doe) v. AttorneyGeneral, para. 6 (19 July 2011), Nevo Legal Database (by subscription) (per N. Hendel J.)

47. A question could be raised about the possible effect of the 'flooding' of the legal profession in Israel over the last years on attorneys' fees. Israel now has probably the highest per capita ratio of lawyers among developed countries; see N. Ziv, 'Unauthorized Practice of Law and the Production of Lawyers in Israel', 19 International Journal of Legal Profession, 175, at 176-8 (2012). Hope has been expressed in the literature that these developments, as well as the proliferation of pro bono services provided by various NGOs, legal clinics, and such might cause the fees to go down in the near future. See T. Fisher and I. Rosen-Zvi, 'It's for the Judges to Decide: Allocation of Trial Costs in Israel', in M. Reimann (ed.), Cost and Fee Allocation in Civil Procedure: A Comparative Study (2011) 177, at 184. This hope seems over-optimistic, as the overproduction of lawyers in Israel is by no means a recent phenomenon, yet has so far failed to have a noticeable influence on the pricing of legal services (as opposed to their quality, which has generally declined).

48. In monetary claims, the basic fee is set at $2.5 \%$ of the amount claimed, of which half is payable upon the filing of the claim and the second half 20 days before the first evidentiary hearing. A different, low fee system exists for non-monetary claims and claims viewed as 'not capable of monetary expression' (such as declaratory judgments, injunctions, specific performance, and ejectment actions.). The obvious result of such a system is that litigants go to great lengths to frame actions as non-monetary. See generally, Court Regulations (Filing Fees), 5767-2007, KT 6579, at 720; Goldstein et al., above n. 19, at 172-4.

49. RCP Chapter 34, Rules 511-519.

50. Fisher and Rosen-Zvi, above n. 47, at 177-8. According to RCP Rule 512(2), the court's decision on costs should take into account, 'among other considerations' (unspecified), the amount or value of the relief sought by the plaintiff and the value actually granted by the court, as well as the manner in which the parties conducted the trial.

51. Id, at 180; Goldstein et al., above n. 19, at 172.

52. For an overview and critical analysis of the Israeli practice in this regard, see T. Eisenberg, T. Fisher \& I. Rosen-Zvi, 'Attorney Fees in a Loser Pays System', 162 University of Pennsylvania Law Review 1619 (2014). According to the authors, litigation costs are denied to prevailing plaintiffs in $26 \%$, and to prevailing defendants in $29 \%$ of all cases, with considerable fluctuations between different types of proceedings; $I d$., at 1640-1645.

53. See e.g. Levin, above n. 21, at 457-8. It should be noted, however, that the verdict of the law and economics literature on the social desirability of (full) fee-shifting, as opposed to the prevailing American rule, under which each party bears its litigation costs, is inconclusive. See generally, e.g. S. Shavell, Foundations of Economic Analysis of Law (2004), at 432; D.P. Kessler and D.L. Rubinfeld, 'Empirical Study of the Civil Litigation System', in A.M. Polinsky and S. Shavell (eds.), Handbook of Law and Economics (2007) 343, at 373-4. 
Court seems to have moved toward favouring full(er) compensation of actual costs, as long as they are 'reasonable, necessary, and proportional'. ${ }^{54}$ Nonetheless, the principle of awarding actual costs is a mere presumption, fairly easily overridden by policy considerations such as avoiding over-deterrence, preventing inequality between rich and poor parties, constraining the costs of litigation, and assuring access to justice. ${ }^{55}$ Ultimately, even under the new approach the actual expenditures of the winning party are but one factor (albeit an important one) considered by the court in its decision on whether to award trial costs at all, and on their amount. ${ }^{56}$ The proposed reform of the Israeli civil procedure, discussed below, does not seem to introduce far-reaching changes into the prevailing system of cost compensation. ${ }^{57}$

\section{Available Simplified Procedures}

\subsection{Small Claims Courts}

Special provisions for dealing with small claims (currently - monetary claims for up to NIS 33,800) were enacted in Israel in 1976, establishing Small Claims
Courts. ${ }^{58}$ These do not constitute a totally separate jurisdictional body but rather a division of the Magistrates' Courts. ${ }^{59}$ Thus, small claims jurisdiction is not exclusive but concurrent; whenever it applies, the plaintiff has a free choice between actually filing a claim in a Small Claims Court or in a 'regular' Magistrates' Court. ${ }^{60}$ If the Small Claims Court finds the claim 'unsuitable' for adjudication before it, it has discretion to transfer the claim to the Magistrates' Court. ${ }^{61}$

The declared aim of the creation of Small Claims Courts was to provide an 'informal, prompt, and cheap' procedure for the benefit of the 'small citizen' who might be deterred from bringing his/her claims before a regular court due to high costs and long delays. ${ }^{62}$ The additional, if undeclared, purpose seems to be alleviating the caseload burden of Magistrates' Courts. Statutory provisions on small claims procedure reflect the above rationales. The filing fee for proceedings before a Small Claims Court is fixed at just $1 \%$ of the value of the claim (as opposed to $2.5 \%$ in regular courts). ${ }^{63}$ Proceedings are initiated by a complaint (statement of claim) that should conform to a simplified form. ${ }^{64}$ Small Claims Courts are not bound by rules of procedure applying to other courts. ${ }^{65}$ They are also entitled to accept evidence which would be inadmissible under general rules. ${ }^{66}$ In case of lack of reply or non-appearance by the defendant, the court shall give judgment solely on the basis of the complaint, subject to the claimant's declaring the veracity of the claims contained

58. Goldstein et al., above n. 19, at 34; Goren, above n. 27, at 1303. The provisions on Small Claims Courts are now incorporated in Chapter B, Part E, of the Courts Law. NIS 33,800 equals approx. EUR 8,000 at the current exchange rate. This sum is adjusted yearly for inflation. See Courts Law, Section 60(a)(1). For comparable jurisdictional limits in countries without a jurisdiction specifically designed to adjudicate small monetary claims, see e.g. in Germany: Local Court (Amtsgericht), Gerichtsverfassungsgesetz (GVG) $\$ 23$ (competence in disputes concerning claims involving an amount or with a monetary value not exceeding EUR 5,000); in France: Court of First Instance (tribunal d'instance), Code de I'organisation judiciare, Art. L221-4 (claims with a value of up to EUR 10,000), and Proximity Court (jurisdiction de proximité) - Art. L231-3 of the same Code (claims of up to EUR 4,000). In England, the upper limit of the small claims jurisdiction was recently raised from GBP 5,000 to GBP 10,000. See N. Andrews, 1 Andrews on Civil Processes (2013), at 94

59. Magistrates' Courts are the lowest tier of the general court system in Israel, with competence over matters not falling into the jurisdiction of District Courts. See above n. 35.

60. Goldstein et al., above n. 19 , at 52

61. Courts Law, Section 60(b). The same discretion applies if the claim was filed by a plaintiff who has filed more than five claims during the same year in the same court.

62. See LCA 292/93 Sarbuz v. O. Ofek Ltd., 48(3) PD 177, at 189-90 (1994); Rosen-Zvi, above note 18, at 154. See also above notes 47-48, and the accompanying text. For an almost literally identical statement of purpose of small claims courts in New York, see J.J. Markwardt, 'The Nature and Operation of the New York Small Claims Courts', 38 Albany Law Review 196, 196 (1974).

63. Small Claims Jurisdiction Regulations, 5737-1976, Section 6(a), KT 3633 , at 510 [hereinafter - Small Claims Jurisdiction Regulations]. See also above n. 47

64. Small Claims Jurisdiction Regulations, Section 3, form 1.

65. Courts Law, Section 62(b).

66. Id., Section 62(A). See also Sarbuz, 48(3) PD, at 190; Goren, above n. 27 , at 1304 . 
therein; ${ }^{67}$ this amounts to a significant alleviation of the habitual burden of proof in civil cases and a deviation from general rules on default judgments. ${ }^{68}$ The court shall give its judgment at the end of the hearing, and in any case no later than 7 days thereafter; the judgment shall be 'succinctly reasoned'. ${ }^{69}$

The advantages (mostly for the claimant) inherent in the small claims procedure do not, however, come without a price. In order to ensure informal and prompt justice at a low cost, the Israeli legislator imposed two major constraints on the parties appearing before the Small Claims Court. First, there is no representation by attorney, except by permission from the court and for special reasons that shall be recorded. ${ }^{70}$ This provision was introduced at the insistence of consumer advocates in order to 'even up the field' between small claimants and large commercial entities; ${ }^{71}$ yet its positive effects on consumers are questionable. ${ }^{72}$ The second limitation concerns the right of appeal: from Small Claims Courts there is no appeal as of right but rather by leave of the appellate court. ${ }^{73}$ Leave for appeal can be given against final judgments only, while 'other decisions' of Small Claims Courts, such as interlocutory orders, are not appealable at all. ${ }^{74}$ The time limit for requesting a leave for appeal in small claims proceedings is 15 days, as opposed to 30 days in proceedings before a regular court. $^{75}$ Constitutional doubts arising out of lack of

67. Small Claims Jurisdiction Regulations, Section 10-11.

68. See LCA 8821/09 Pruzhansky v. Laila Tov Hafakot Co., paras. 10-11 (16 November 2011), Nevo Legal Database (by subscription) (per Y. Danziger J.). However, these provisions do not absolve the court from the duty to establish whether the facts stated in the complaint prima facie establish a valid claim. Id., para. 12 .

69. Small Claims Jurisdiction Regulations, Section 15

70. Courts Law, Section 63(a). See also S. Becher and A. Klein, 'Paradoks ha-Yitzug ve-ha-Ko'ah be-Beit ha-Mishpat le-Tvi'ot Ktanot?' ['Paradox of Representation and Power in the Small Claims Court?'], $50 \mathrm{Ha}$-Praklit 327, 336-7 (2010) (in Hebrew); Goren, above n. 27, at 1304-1305.

71. See LCA 6892/13 Haymovich v. Ohayon, para. 11 (23 February 2014), Nevo Legal Database (by subscription) (per E. Rubinstein J.) (the aim of the 'non-representation' provision is to 'preserve equality and symmetry between the parties in the Small Claims Court and prevent a situation in which the preponderant power of one side creates an asymmetry in representation').

72. Goldstein et al., above n. 19, at 29-30. The consumer rationale of the 'non-representation' rule can also be circumvented - or even eviscerated - by 'repeat players', such as insurance companies, with negative consequences for all parties. See Becher and Klein, above n. 70, at 345-84; on the distinction between 'repeat players' and 'one-shotters' in litigation see the seminal article by M. Galanter, "Why The "Haves" Come Out Ahead: Speculations on the Limits of Legal Change', 9 Law \& Society Review 95 (1974). Recently, Supreme Court Justice Rubinstein subjected this practice to scathing critique, emphasising that Courts Law, at Section 62(B), specifically prohibits the use of 'professional representatives' by corporate parties in Small Claims Courts, while representation by a 'case worker' is acceptable; see LCA 6892/13 Haymovich, paras. 12-14. What influence this decision will have on future litigation practice remains to be seen.

73. Courts Law, at Section 64

74. See Sarbuz, 48(3) PD, at 191, 200; Goren, above n. 27, at 1307. On the distinction between 'judgments' and 'other decisions' in Israeli civil procedure in the context of appeal rights, see Goldstein et al., above n. 19 , at 34-5.

75. Small Claims Jurisdiction Regulations, at Section 16(a); Goren, above n. 27 , at $1305,1308$. appeal as of right from Small Claims Courts ${ }^{76}$ have been dismissed by the Supreme Court. ${ }^{77}$ Furthermore, the jurisprudence has developed a strikingly parsimonious attitude towards the grounds justifying granting leave for appeal. ${ }^{78}$ Leave will not be granted unless there is an obvious mistake of fact or law on the part of the Small Claims Court - a mistake which can be established without requiring extended discussion or preliminary pleadings. ${ }^{79}$ The mere fact that the court's decision raises a question of legal or public importance on which no clear case law exists does not itself justify granting leave for appeal, as small claims procedure is not considered suitable for the development of legal doctrine. Rather, leave should be granted only if the relevant question is of the kind frequently addressed by Small Claims Courts, in order not to perpetuate a mistaken judgement which might serve as precedent to the court which gave it. ${ }^{80}$

The Small Claims Court as an institution has proven to be a resounding success in Israel. Over time, it has developed into a veritable consumer affairs court and acquired a central position in the Israeli system of consumer protection. ${ }^{81}$ In 2013 , over $14 \%$ of all actions in Magistrates' Courts were filed under the small claims track, highlighting its indispensability. ${ }^{82}$ One indication of the Small Claims Court's wide popularity is its jurisdictional limit being raised over the years far beyond the inflation rate; so, in 2008 the maximum monetary amount within the court's jurisdiction was almost doubled. ${ }^{83}$ This increase was wholeheartedly supported by Israel's chief consumer protection organisation. ${ }^{84}$ The prevailing consensus in Israel is that the institutional and procedural design of the Small Claims Court, which guarantees important advantages to litigants who are

76. See Goldstein et al., above n. 19, at 34; minority opinion of S. Levin J. in Sarbuz, 48(3) PD, at 184-5.

77. Sarbuz, 48(3) PD, at 193-4, 196 (per D. Levin J.).

78. See generally, Goren, above n. 27, at 1308.

79. LA (Jer') 244/90 Ya'ir v. Frenkel, PM 5751(3) 309, 314 (1991); LSC (Hi') 45991-02-14 Tzadok v. Pelephone Communications Ltd., para. 24 (25 August 2014), Nevo Legal Database (by subscription).

80. See Ya'ir, PM 5751(3), at 315; LA (Jer') 375/08 Arkia Israel Airlines v. Korakh, para. 10 (3 April 2008), Nevo Legal Database (by subscription); LCA 2095/15 Neptune Halls Bat-Yam Ltd. v. Mashiah, para. 4 (20 May 2015), Nevo Legal Database (by subscription) (per Z. Zilbertal J.). The proper way for a Small Claims Court judge confronted with a new and important legal question would be to transfer the case to the Magistrates' Court, in accordance with Courts Law, at Section 60(b). See LA (Jer') 375/08 Arkia Israel Airlines, para. 10.

81. See Sinai Deutch, 'Beit ha-Mishpat le-Tvi'ot Ktanot ke-Magen ha-Tsarkhan' ['The Small Claims Court as Protector of the Consumer'], 8 lyunei Mishpat 345 (1981) (in Hebrew); Becher and Klein, above n. 70, at 334 n. 28.

82. Yearly Report 2013, above n. 33, at 26

83. Courts Order (Change of Claim Amount in Small Claims), 5768-2008, KT No. 6702, at 1228. See also Becher and Klein, above n. 70, at 334 n. 29.

84. As expressed during the Knesset debate by Adv. Yael Cohen-Shawat, Legal Adviser to the Israel Consumer Council. See The Knesset, Constitution, Law and Justice Committee, Protocol no. 598 (7 July 2008), available via the Knesset website at: <www.knesset.gov.il/protocols/ heb/protocol_search.aspx>. The dissenting voices at the debate preceding the Knesset Committee's vote on raising the bar of small claims came, rather pointedly, from representatives of the Israeli Bar and of the Manufacturers' Association, who took specific exception with the attorney representation ban. Id. 
indigent or of modest means, is justified in terms of promoting substantive procedural equality at the expense of truth discovery; the bargain struck between these two values is regarded as acceptable and even optimal. ${ }^{85}$ It is no wonder, therefore, that the current small claims procedure is not affected at all by the proposed civil procedure reform. ${ }^{86}$

\subsection{Summary Procedure}

The origins of the Israeli summary procedure (seder din mekutsar), now codified in RCP, Rules 202-214, can be found in the Order 14 of the Rules of the Supreme Court of England. ${ }^{87}$ The development of the procedure in Israel has, however, largely deviated from the (now defunct) English model. ${ }^{88}$ In fact, in its present form it bears more resemblance to procedures available in some Continental systems, such as the Italian procedimento d'ingiunzione ${ }^{89}$ or the German Urkundenprozess ('documentary procedure'), ${ }^{90}$ though the scope of the Israeli procedure is much wider.

Rule 202 of the RCP provides for the types of claims that may be commenced by way of summary procedure. The most important category consists of claims for a liquidated sum of money, with or without interest, 'based on an express or implied contract or undertaking, provided there is written evidence thereof ${ }^{91}$ Filing a claim under the summary procedure entails - in contradiction to the generally applying principles of civil litigation $-\mathrm{a}$ circumscription of the defendant's right to oppose the action. In order to do so, the defendant is required to apply for leave to defend; the application must be supported by an affidavit elaborating the defence in detail. ${ }^{92}$ This requirement imposes on the defendant a duty to adopt a fixed line of defence from the outset of the proceedings, as opposed to the flexibility allowed under the

85. See Rosen-Zvi, above n. 18, at 153-4. It is worth mentioning in this context that at the 2008 Knesset Committee debate, the proposal to combine raising the bar of small claims with granting a right of appeal was immediately and nearly unanimously rejected. See The Knesset, Constitution, Law and Justice Committee, Protocol no. 598, above n. 84.

86. See below, Section 4.1. The reform concerns only the RCP which do not apply in Small Claims Courts.

87. On the English origins of summary procedure in Israel, see generally, E. Livneh, 'Summary Procedures in Israel and Abroad', 2 Israel Law Review 210, at 210-2 (1967).

88. See Stephen Goldstein, 'Summary Judgment Proceedings in Israeli Law', in A.M. Rabello (ed.), Israeli Reports to the XV International Congress of Comparative Law (1999) 183, at 187.

89. See S. Grossi and M.C. Pagni, Commentary on the Italian Code of Civil Procedure (2010), at 409-19; Goldstein (1999), above n. 88, at 187.

90. See generally, Livneh, above n. 87, at 215-6; W. Mertins, 'Der Urkundenprozess', 2012 Neue Justiz 133; A. Leidig and J. Jöbges, 'Sämtliche sind ausnahmlos alle - Zur Zulässigkeit des Urkundenprozesses', 2014 Neue Juristische Wochenschrift 892.

91. RCP, Rule 202(1)(a). Additional types include claims for liquidated sums of money arising out of an express statutory provision (Rule 202(1)(b)); claims by a local authority for liquidated sums due to it for municipal taxes, levies, fees, or participation charges (Rule 202(2); claims for eviction from land or rental premises, provided there is written evidence regarding them (Rule 202(3)). See also Goren, above n. 27, at 786

92. See RCP, Rule 205(a); CA 9654/02 Alfi Brothers Co. v. Le'umi Bank of Israel, 59(3) PD 41, 46 (2004) (per J. Türkel J.); CA 527/07 Nahum v. Aharonson Fund Ltd., para. E(2) (18 February 2008), Nevo Legal Database (by subscription) (per E. Rubinstein J.). general rules. ${ }^{93}$ In a summary procedure case, the court is authorised to base its decision solely on the written motions by the parties (the complaint and the application for leave to defend), and the hearing held on the defendant's application. ${ }^{94}$ Moreover, the application may be rejected - for reasons that are to be recorded even without conducting a hearing on the matter. ${ }^{95}$ The court also has discretion to make the leave to defend conditional or limited to certain terms. ${ }^{96}$

Obviously, the above features of summary procedure offer considerable procedural advantages to the claimant. ${ }^{97}$ It is especially so given the fact that the sanction for improperly bringing a claim within the summary procedure framework is not dismissal, but merely the striking out of the heading of the complaint and its transfer to the ordinary track. ${ }^{98}$ These advantages can be justified in light of the summary procedure's conception as an expedited debt collection device. ${ }^{99}$ Its rationale lies in the presumption that the defendant has no valid defence. ${ }^{100}$ The debt collection rationale is evident in the transfer of two kinds of claims originally falling within the scope of summary procedure, to the competence of execution offices, thus eliminating the need to initiate a court proceeding altogether. First, claims of holders of negotiable instruments were made directly

93. The accepted practice in Israel makes it possible for the defendant to limit himself/herself, in the statement of defence, to a denial of the factual allegations made by the claimant, without presenting a coherent own version of events. See Goldstein et al., above n. 19, at 104

94. CA 5480/98 Menora Insurance Co. v. Abo, 52(4) PD 476, at 479 (1998); LCA 1265/08 Mondar v. Harel Insurance Co. Ltd., para. D(3) (27 April 2008), Nevo Legal Database (by subscription) (per E. Rubinstein J.).

95. RCP, Rule 205(g). This provision follows the (general) rule concerning interlocutory motions set out in Rule 241(d), according to which the court may decide on the motion without cross-examination of the affiant. See Goldstein et al., above n. 19, at 109.

96. LCA 271/14 Raz v. Peled (27 January 2014), Nevo Legal Database (by subscription).

97. The previous incarnation of the Israeli RCP, adopted in 1963, contained a provision enabling setting an expedited trial date ('queue jumping') for cases filed under the summary procedure, once leave to defend had been granted. This provision was dropped from the 1984 version of $\mathrm{RCP}$, but for some time confusion remained as to whether the practice of 'queue jumping' continued to persist in Israeli courts. See Goldstein et al., above n. 19, at 111, 113-4. It seems, however, that by now this practice has been abandoned, and once leave to defend is granted, the file is simply routed to the regular track. See Schwartz, above n. 21, at 310.

98. See Goldstein (1999), above n. 88, at 194. In comparison, under German law, non-compliance with the pre-requirements of the 'documentary procedure' leads to the claim's dismissal by the court. See Code of Civil Procedure (Zivilprozessordnung, ZPO) § 597 II; Mertins, above n. 90, at 135; Leidig and Jöbges, above n. 90, at 893.

99. Goldstein et al., above n. 19, at 110. For a similar view of the German documentary procedure, see e.g. OLG München, Urt. v. 21.9.2011 - 7 U 4956/10, Rz. II.1.e), available at: <http://openjur.de/u/493791. html>.

100. Goldstein et al., above n. 19, at 111. See also Alfi Brothers Co., 59(3) PD, at 46; CA 1471/06 Agiv Consulting and Management Ltd. v. Rabinowitz, para. 5 (6 March 2008), Nevo Legal Database (by subscription) (per E. Hayut J.); LCA 8364/07 Menora Insurance Co. Ltd. v. El Al Israel Airlines Ltd., para. 6 (13 March 2011), Nevo Legal Database (by subscription) (per A. Grunis J.). 
enforceable, ${ }^{101}$ and since 2002 - claims for liquidated sums not exceeding NIS 50,000, increased to NIS 75,000 in 2015 (approx. EUR 18,300 at the current exchange rate). ${ }^{102}$ Only if the debtor files an 'objection' to the claim (equivalent to the application for leave to defend), is the file transferred to the competent court to be dealt with according to the summary procedure. ${ }^{103}$

And yet the liberal attitude vis-à-vis the summary procedure by the Israeli jurisprudence - which does not seem to be shared by other jurisdictions ${ }^{104}$ - has resulted in its extension beyond the narrow rationale of (presumably uncontested) debt collection. ${ }^{105}$ The primary reason for this trend lies with the relaxation of the written evidence requirement. This precondition for the application of summary procedure was taken to require (based on an analogy from an unrelated provision of the French Code civil, dealing with the admissibility of oral versus written evidence) ${ }^{106}$ not full or complete proof in writing of all elements of the claim, but merely a 'commencement of proof' (commencement de preuve), to which oral evidence could be adduced. ${ }^{107}$

As a counterweight to their rather lax handling of the elements of Rule 202 delineating the applicability of the summary procedure, ${ }^{108}$ Israeli courts have adopted a

101. The relevant provision is Section 81A of the Execution Law, 5727-1967, 21 LSI 112 (1966-67), as amended in 1968. See also Goldstein et al., above n. 19, at 111 .

102. See Execution Law, Section 81A1; Goren, above n. 27, at 789. For the 2015 amendment, see Execution Law (Amendment No. 46), 5776-2015, SH No. 2495, at 196.

103. Execution Law, Section $81 \mathrm{~A}(\mathrm{c}), 81 \mathrm{~A} 1(\mathrm{~d})$.

104. In Germany, the restrictive interpretation of the documentary procedure's scope of application has been lately justified on the basis of its 'systemic incompatibility' (Systemwidrigkeit) with the general principles of German procedural law. See M. Fervers, 'Urkundenprozess bei Werklohnforderungen', 2014 Zeitschrift für das Juristische Studium 337, $343,345$.

105. See Goldstein (1999), above n. 88, at 195; A. Klement and R. Shapira, 'Ya'ilut ve-Tsedek be-Seder ha-Din ha-Ezrahi - Gisha Parshanit Hadasha' ['Efficency and Justice in Civil Procedure - A New Interpretative Approach'], 7 Mishpat ve-Asakim 75, 105 n. 103 (2007) (in Hebrew).

106. Art. 1341 of the French Code prescribes for the more important contracts the requirement of evidence in writing; Art. 1347 confines this requirement to a commencement de preuve par écrit. The French Code was used by the Israeli jurisprudence in the interpretation of the evidentiary provision of Art. 80 of the Ottoman Code of Civil Procedure, still in force in Israel, which is similar to Art. 1341 of the Code civil. See generally Livneh, above n. 87, at 213.

107. See CA 236/64 'Arda' Co. v. Katz, 18(3) PD 518, 522 (1964); CA 465/66 Gelbar v. Turner, 20(4) PD 772, at 775-6 (1966); Goren, above n. 27 , at 785 . In contrast, the German jurisprudence demands, in principle, documentary proof in relation to all the facts contained in the claim, in order for the claim to be admissible under the documentary procedure track. See Mertins, above n. 90, at 134-5. Recently, a new and even more restrictive interpretation has been adopted by the Court of Appeals in Schleswig. The court ruled, breaking with earlier jurisprudence, that the above requirement cannot be waived even concerning the facts that are not in dispute between the parties. See OLG Schleswig, Urt. v. 30.8.2013 - 1 U 11/13, 2014 NJW 945. This approach received favourable reviews from the commentators. See Leidig and Jöbges, above n. 90, at 895; Fervers, above n. 104, at 343.

108. As to the expansive interpretation of the 'contract or undertaking' and 'liquidated sum' requirements, see Summ. 609/65 Rozovsky v. Zbeideh, 20(1) PD 236 (1966); Goren, above n. 27, at 784. However, it has been held that subrogation claims in personal injury actions are generally not well-suited for the summary procedure track. See LCA 8364/07 Menora Insurance Co., paras. 10-13 (per A. Grunis J.). lenient approach towards granting leave to defend, which effectively reinstates the claim upon the regular procedural track. ${ }^{109}$ According to the jurisprudence, the court's disposition of the motion for leave should not be used as a substitute for judging the merits of the case. ${ }^{110}$ At this stage, it is sufficient for the defendant to show a prima facie defence, which may be based on oral against written evidence; 111 the application for leave will be rejected only if it is clear beyond doubt that the defence has no chance of succeeding. ${ }^{12}$ The mere fact that the defence lacks credibility in the eyes of the court is not sufficient ground per se to deny the leave to defend. ${ }^{113}$ This approach is largely motivated by the constitutional concern over unduly restricting the defendants' right of access to courts. ${ }^{114}$ However, the accommodating policy vis-à-vis the defendants should by no means be construed as effectively nullifying the utility of the summary procedure for the claimant. In most cases initiated under the procedure, leave to defend is not requested in the first place; where the defendant does apply for the leave, and even in large claims, its granting is not assured. ${ }^{115}$ Leave to defend will be denied if the defendant can only put up a 'sham defence' - i.e. one that is manifestlyuntrue, insufficient, or irrelevant on its face or if the defence collapses entirely under cross-examination. ${ }^{116}$ Although the quality of the defendant's evidence is not examined in depth at the application for leave to

109. See Goldstein et al., above n. 19, at 109; Klement and Shapira, above n. 105 , at 105 n. 103.

110. CA 10189/07 Sasson v. Mizrahi Tefahot Bank Ltd., para. 8 (15 June 2009), Nevo Legal Database (by subscription) (per Y. Danziger J.).

111. Goldstein et al., above n. 19, at 109; CA 10189/07 Sasson, para. 8 (per Y. Danziger J.).

112. Alfi Brothers Co., 59(3) PD, at 46; CA 10189/07 Sasson, para. 8 (per Y. Danziger J.); CA 1471/06 Agiv Consulting and Management Ltd., para. 5.

113. CA 518/87 Pateljean v. Union Bank of Israel (25 November 1993), Nevo Legal Database (by subscription); CA 10189/07 Sasson, para. 8 (per Y. Danziger J.).

114. See Goldstein et al., above n. 19, at 109; CA 10189/07 Sasson (per A Procaccia J.).

115. According to a study conducted in 1980 in the course of the deliberations of the Advisory Committee on Civil Procedure appointed by the Minister of Justice, applications for leave to defend were filed in less than $10 \%$ of the summary procedure claims falling within the jurisdiction of the Magistrates' Courts, and in more than half of the claims filed in the District Courts. The leave was granted in $24 \%$ to $37 \%$ of cases by the Magistrates' Courts, with the rate of success rising to a little over $50 \%$ at the District Courts level. See Goldstein (1999), above n. 88, at 198-9. In 2002, during parliamentary debates over the proposal to broaden the 'direct execution' track (see above, notes 102-103, and accompanying text), roughly similar figures were presented (applications for leave to defend filed in $15 \%$ of cases with about half the applications successful). See The Knesset, Constitution, Law and Justice Committee, Protocol no. 429 (29 January 2002), available via the Knesset website at: <www.knesset.gov.il/protocols/heb/protocol_search. aspx>. Even more stark is the data offered recently in the context of raising the maximum limit of 'direct execution' claims: a motion for leave to defend is filed in only $4 \%$ of these claims, and its rate of success stands at $15 \%$. See The Knesset, Constitution, Law and Justice Committee, Protocol no. 20 (7 July 2015), available via the Knesset website at: <www.knesset.gov.il/protocols/heb/protocol_search.aspx>.

116. See CA 1471/06 Agiv Consulting and Management Ltd., para. 5; CA $527 / 07$ Nahum, para. E(3). Nahum provides an example of a sham defence in the summary procedure context: claim of a promise by a deceased person unsubstantiated by any external evidence. Id., para. $E(4)$. 
defend stage, the defendant's (low) probability of success is a factor that can be taken into account by the court when deciding to subject the leave to conditions or impose a security on the defendant. ${ }^{117}$

Over the years, summary procedure has become a 'deeply rooted' Israeli institution, ${ }^{118}$ despite being considered an exception to general procedural rules. ${ }^{119}$ Attempts to abolish the procedure in Israel have so far been unsuccessful, largely due to the stubborn resistance of the trial lawyer community. ${ }^{120}$ Indeed, some commentators have observed that the efficiency rationale for creating a separate privileged track for claimants with a prima facie sound claim appears sound. ${ }^{121}$ And yet, summary procedure has been subject to harsh and mounting criticism. The arguments against it are varied. It is denounced by some en bloc as disproportionately favouring the claimants (often of the institutional 'repeat player' variety, such as banks) to the detriment of the defendants, especially those of limited means, thus impairing the principle of equality and the right of access to court. ${ }^{122}$ On a more pragmatic level, the current summary procedure has been criticised for being overextended in scope beyond its original debt collection rationale. ${ }^{123}$ It has also been asserted that in many cases the Israeli summary procedure fails to achieve its designated purpose of providing a mechanism to swiftly dispose of certain types of (presumably well-grounded) claims. ${ }^{124}$ Albeit some of the deficiencies of summary procedure, as it exists today, could probably be addressed by a limited reform, ${ }^{125}$ proposals to scrap this institution altogether have gained currency in recent years. Abolition of summary procedure was recommen-

117. Alfi Brothers Co., 59(3) PD, at 47; CA 527/07 Nahum, para. E(8)

118. This was the argument put forward against abolishing the procedure, when the issue came under discussion in the early 1980s. See Y. Danziger, 'Ha-Va'ada ha-Meya'etset le-Inyan Seder ha-Din ha-Ezrahi (Va'adat Etzi'oni)' [The Advisory Committee on Civil Procedure (Etzi'oni Committee)], 34 Ha-Praklit 159, 162 (1981) (in Hebrew).

119. See Menora Insurance Co., 52(4) PD, at 479 (per A. Barak CJ); Goren, above n. 27 , at 783

120. On the proposals to abolish the procedure in the 1970s and their ultimate failure, see Danziger, above n. 118, at 161-2. It might be worth noting, in comparison, that in France a (more or less) similar procedure had existed under Arts. 404-413 of the 'old' Code of Civil Procedure, but was gradually repealed and is absent from the new Code adopted in 1975. See P. Herzog and M. Weser, Civil Procedure in France (1967), at 488-94; A. Kohl, 'Romanist Legal Systems', in M. Capeletti (ed.), XVI-6 International Encyclopedia of Comparative Law, Civil Procedure (1984) 57, at 88.

121. See Schwartz, above n. 21, at 293-6; Klement and Shapira, above n. 105 , at 107 . This rationale was also highlighted in the explanatory note to the bill introducing the 'direct execution' track in 2002. See Execution Law Bill (Amendment No. 25) (Summary Procedure Claims), 5762-2002, HH No. 3147, at 714.

122. See Rosen-Zvi, above n. 18, at 154-5. On the inherent advantages of 'repeat players' vis-à-vis 'one-shotters' in civil litigation, see generally, Galanter, above n. 72; S. Talesh, 'How the "Haves" Come out Ahead in the Twenty-First Century', 62 De Paul Law Review 59 (2013).

123. See Goldstein (1999), above n. 88, at 195-6, 201-2; Schwartz, above n. 21, at 309-10.

124. As explained by Schwartz, above n. 21, at 310-1, this is due to the courts' lenient handling of leave to defend motions, on the one hand, and of lack of priority in handling claims originally filed under the summary procedure, once the leave to defend has been granted, on the other hand. ded in the 2008 'Ronen Report' dealing with the ways to improve the effectiveness of court proceedings in Israel. ${ }^{126}$ The report's recommendation has been adopted in the 2014 Draft Rules. ${ }^{127}$ This does not mean, however, that the fate of summary procedure in Israel is sealed. Even in the event the Draft Rules in their proposed version ultimately become black-letter law, which is by no means certain, ${ }^{128}$ they will not affect the 'direct execution' track described above - which is, in practice, the summary procedure's particularly important incarnation and has just recently been expanded. ${ }^{129}$ Moreover, data from a recently published study of judicial workload in Israel show that the summary track does indeed provide for significantly shorter delays in disposing of cases. ${ }^{130}$ These findings, although insufficient in themselves for a comprehensive assessment of its role and desirability, have been brought up in the recent polemic against the Draft Rules as at least necessitating a thorough justification for abolishing the summary procedure, based on empirical evidence. ${ }^{131}$ Another argument in favour of retaining the summary track is its contribution to reducing the parties' (and especially the debtors-defendants') trial costs ${ }^{132}$ and to encouraging

125. For some suggestions, see $/ d$., at 311-3. These include, inter alia, beefing up the 'written evidence' requirement in order to assure that only well-substantiated claims are privileged; holding an immediate hearing on the merits in cases where the defence is manifestly weak; empowering court registrars to decide on motions for leave to defend; and giving the court wide discretions to transfer cases from the summary to the regular track.

126. State of Israel, Courts Administration, Du'akh ha-Va'ada li-Vhinat Darkei Ye'ul ha-Halikhim ha-Mishpati'im be-Reshut Kvod ha-Shofetet Ruth Ronen [Report of the Commission on the Ways to Improve the Effectiveness of Legal Proceedings, Headed by Esteemed Judge Ruth Ronen] (2008), at 4-6 (in Hebrew), available at: <http://elyon1.court. gov.il/heb/veadot/vaadat_ronen.pdf> [hereinafter: Ronen Report].

127. Draft Rules, above n. 30, at 2. The Draft Rules put forward a special fast track procedure for eviction claims from rented premises, which currently fall under the scope of the summary procedure. See $/ d$., at 49. See also above, n. 91.

128. See below, Section 4.2 .

129. Rule 23 of the Draft Rules describes a 'leave to defend [procedure] arising from legislation'. The legislation in question is Execution Law, Section 81A-81A1; see above notes 101-103.

130. The study is based on the internationally accepted 'case weights' methodology, designed to measure relative time length necessary for adjudicating various types of cases. See K. Weinshall-Margel, I. Galon \& I. Taraboulos, 'Yetsirat Madad Mishkalot Tikim le-Ha'arakhat ha-Omes ha-Shiputi be-Yisra'el' ['Creating a Case Weight Index for Measuring Judicial Workload in Israel'], 44 Mishpatim 769 (2015) (in Hebrew). According to the study, the aggregated 'weight' of a summary procedure case is 5.3 times 'lighter' than that of its regular procedure counterpart in a Magistrates' Court, and 2.7 times - in a District Court. Seeld., at 813-4, Table 2.

131. See E. Taussig and A. Kleiman, 'Ha-Omnam Tovim ha-Shnayim min haEhad? Ribuy Maslulim le-Hagashat Tov'ana Ezrahit' ['Is Two Better Than One? Multitude of Tracks for Initiating Civil Proceedings'], Part E. 1, Paper Presented at the Faculty of Law, Tel Aviv University, March 2015 (on file with the author) (in Hebrew).

132. This point was stressed both in the explanatory notes to the 2015 bill proposing to raise the bar of 'direct execution' claims - see Execution Law Bill (Amendment No. 46), 5775-2015, HH (Gov.) No. 920, at 608 - and in the subsequent Knesset Committee debate: see The Knesset, Constitution, Law and Justice Committee, Protocol no. 20, above n. 115. See also below notes 174 and 175 , and the accompanying text. 
settlements. ${ }^{133}$ Some writers also point out that its existence is likely to positively affect the behaviour of the parties ex ante. ${ }^{134}$ The survival of this privileged track, at least in some form, therefore seems assured, even though its overall record within the Israeli system remains controversial. ${ }^{135}$

\subsection{Fast Track Procedure}

In 2001, an important innovation was introduced into the Israeli civil procedure system. An amendment to RCP added Rules 214A-214P, creating a new 'fast track' procedure (seder din mahir). The amendment was clearly inspired by - and closely modelled on - the 1998 reform of English civil procedure as a result of the recommendations of the Woolf Report. ${ }^{136}$ The fast track is specifically designed for claims not exceeding NIS 75,000 (approximately EUR 17,750 at the current exchange rate $)^{137}$ filed in Magistrates' Courts under the regular or the summary procedure (the latter in cases when leave to defend has been granted), as well as for those transferred from the Small Claims Courts. ${ }^{138}$ Nevertheless, a Magistrates' Court has wide discretion to transfer claims from the fast to the regular track ${ }^{139}$ and vice versa (in the latter case subject to the consent of all parties). ${ }^{140}$ In making these determinations the court is to consider factors such as the complexity of the facts, issues, and evidence involved; the number of parties; the complications caused by the existence of counterclaims and impleaders; the extent of required oral evidence and expert testimony; the implications of the case for the general public; as well as the importance of the claim's speedy resolution, in light of its nature and the identity of the parties. ${ }^{141}$

The chief purpose of the fast track procedure is to make sure that the proceedings are conducted efficiently and within a short timeframe, reducing administrative costs in a way commensurate with the relatively low sums involved. ${ }^{142}$ The fast track, thus, obviously shares a common goal with the small claims procedure. ${ }^{143}$ This goal is reflected in the provisions imposing on parties in fast track cases various obligations not required under the regular procedure. These include the duty to support the pleadings by affidavits verifying the facts alleged and to attach expert opinions and legal authorities to the pleadings. ${ }^{144}$ The parties are also enjoined to provide 'early disclosure': they must attach a list of all documents relevant to the case (and not only those on which they intend to rely) as well as the relevant documents themselves, as long as they are in their possession. ${ }^{145}$ Another innovative requirement concerns witness affidavits: these must be filed within 45 days after the pleadings, and serve as substitute for the direct examination of the witnesses; a witness from whom an affidavit has not been provided is precluded from testifying at the trial, except by special permission of the court. ${ }^{146}$ In order to expedite the fast track proceedings, limitations are also imposed on the filing of counterclaims and impleaders, as well as on obtaining prelimi-
133. On inducing settlements as a chief social purpose of the institution of trial, see Shavell, above n. 53, at 415. According to (partial) data set forth during the 2015 Knesset Committee debate, up to $75 \%$ of cases where an application for leave to defend is filed at end in a settlement. See The Knesset, Constitution, Law and Justice Committee, Protocol no. 20, above n. 115.

134. See Klement and Shapira, above n. 105, at 106-7; Taussig and Kleiman, above n. 131, Part E.2.

135. Compare the negative assessment by Rosen-Zvi, above n. 18, at 156-7 (viewing the summary procedure as an inegalitarian 'procedural barrier') with the more positive opinion of Taussig and Kleiman, above n. 131, Part B.1 (the summary procedure track represents a balancing of the need to save judicial time on the one hand, and the interests of fairness and truth discovery on the other). See also the various arguments raised during the 2015 Knesset Committee debate: The Knesset, Constitution, Law and Justice Committee, Protocol no. 20, above n. 115.

136. See R. Cohen and M. Klein, Seder Din Mahir be-Beit Mishpat ha-Shalom [Fast Track Procedure at the Magistrates' Court] (2005), at 7-9 (in Hebrew); Goldstein et al., above n. 19, at 114, 115-6; Taussig and Kleiman, above n. 131, Part B.3. For an economic analysis of the Woolf reform in England, see A. Ogus, 'Civil Procedure Reform and Economic Analysis', in C. Ott and G. von Wangenheim (eds.), Essays in Law and Economics IV: Public Law, Private Law, and Adjudication (1998) 237.

137. The original ceiling was set at NIS 50,000 and was raised to NIS 75,000 by an amendment to RCP adopted in 2009; see KT 6902, at 1920. In comparison, the fast track procedure in England is currently subject to a GBP 25,000 ceiling. See Andrews, above n. 58, at 94-5.

138. RCP, Rules 214B, 214B1. Road accident compensation claims and class actions are generally excluded from the fast track. See Goldstein et al., above n. 19, at 115; Goren, above n. 27, at 883-5.

139. RCP, Rule $214 \mathrm{~L}$.

140. Id., Rule $214 \mathrm{~B}(\mathrm{~b})$
141. Id., Rule 214L(b). See also, Goren, above n. 27, at 885. Another factor, suggested by the jurisprudence, is the potential impact of the case on further litigation. So, Judge Gerstel from the Tel-Aviv District Court decided to transfer a claim from the fast to the regular track when it became clear that it was a 'first shot' in a potentially large-scale consumer litigation, involving scores of claimants; see LA (TA) 1977/02 Neve Schuster Co. Ltd. v. Harush (14 July 2003, unreported). See also A. Orenstein and Y. Efron, 'Le'an Ne'elam Seder ha-Din ha-Mahir? O Kulanu Seder Din Mahir?' ['Where Did the Fast Track Procedure Disappear? Or Is It All Fast Track Procedure Now?', Part D.3, paper presented at the Faculty of Law, Tel Aviv University, March 2015 (on file with the author) (in Hebrew).

142. See LCA 646/14 Ashtrom Contracting Co. v. New Kopel Ltd., para. 7 (8 May 2014), Nevo Legal Database (by subscription) (per Z. Zilbertal J.); Goldstein et al., above n. 19, at 116. The explanatory notes published by the Ministry of Justice to the final version of the rules introducing the fast track procedure also emphasised that in the cases involved the swift resolution of the dispute and the reduction of costs are particularly important to the parties themselves. See Cohen and Klein, above n. 136 , at 9,66 . On the efficiency rationale of the fast track procedure, see also Orenstein and Efron, above n. 141, Part B.

143. LCA 646/14 Ashtrom Contracting Co., para. 7.

144. RCP, Rule 214C; LCA 3312/04 Assurances générales de France v. Official Receiver, 60(3) PD, at 245, 252 (2005) (per A. Grunis J.).

145. RCP, Rule 214H; see also Goren, above n. 27, at 888 ; Orenstein and Efron, above n. 141, Part D.2. Thus, disclosure becomes an integral part of the pleadings themselves, whereas the general Israeli rule sees it as part of the discovery process taking place after the pleadings. See Goldstein et al., above n. 19, at 117.

146. RCP, Rule 214l; see also Goldstein et al., above n. 19, at 117. 
nary relief. ${ }^{147}$ The court may hold only one pre-trial conference, and the trial itself should normally take place over a single day. ${ }^{148}$ The judgment in a fast track case is to be rendered immediately after the trial and in any case no later than 14 days thereafter; the reasons must be concise unless a more detailed reasoning is required due to the novelty or the public importance of the case. ${ }^{149}$ Although the fast track provisions of the RCP do not themselves contain any limitations on the right of appeal, the goals of the fast track procedure dictate a particularly restrictive review policy of fast track judgments by appellate courts, and especially by the Supreme Court. ${ }^{150}$

As evident from the overview above, the fast track procedure is based on two complementary principles: severe restriction of the litigants' procedural freedom to shape the proceedings and their course, coupled with a relative increase of the administrative powers of the judge. ${ }^{151}$ Nonetheless, even the latter's discretionary powers are curtailed in comparison with the regular procedure by inflexible time limits. ${ }^{152}$ The fairly rigid nature of the fast track procedure was criticised immediately after its adoption, and many of its provisions were even declared void in a (later overturned) Magistrates' Court decision, as being contrary to the constitutional right to a fair hearing and violating the principle of judicial independence. ${ }^{153}$ However, despite initial doubts and criticism, the controversy rapidly subsided, and the fast track has been universally accepted as essential and

147. RCP, Rules $214 \mathrm{E}-214 \mathrm{~F}, 214 \mathrm{M}$. A counterclaim may be filed only if it does not involve additional parties that are not already part of the action and if it is either itself suitable for the fast track or arises of the same transaction or occurrence as the original claim; an impleader may only be filed after obtaining permission by the court. Restrictions on preliminary relief, on the other hand, are not substantial, but rather apply to the timing of applications and to the decision process. See Goldstein et al., above n. 19, at 117-8; Goren, above n. 27, at 887-8, 890-1; Orenstein and Efron, above n. 141, Part D.1.

148. RCP, Rules $214 \mathrm{~K}, 214 \mathrm{~N}$. In order to facilitate a settlement between the parties, it is specifically provided that the parties themselves must attend the pre-trial conference. $I d$., Rule $214 \mathrm{~K}(\mathrm{e})$; see also Goldstein et al., above n. 19, at 119

149. RCP, Rule 214P. See also Goren, above n. 27, at 891; Goldstein et al., above n. 19, at 120. This is similar to the provisions applying in Small Claims Courts. See above n. 69, and the accompanying text.

150. See LCA 646/14 Ashtrom Contracting Co., para. 7.

151. See Schwartz, above n. 21, at 280-1. The court's authority to limit the examination of witnesses, under RCP, Rule $214 \mathrm{~N}(\mathrm{c})$ is central in this regard.

152. See Orenstein and Efron, above n. 141, Part B; Schwartz, above n. 21, at 281.

153. See CC (Jerusalem Magistrates' Ct.) 4050/01 Municipality of Jerusalem v. Muhammad (16 July 2002), Nevo Legal Database (by subscription). This decision by Judge M. Agmon-Gonen was reversed on appeal to the District Court: CA (Jer') 3350/02 Attorney-General v. Municipality of Jerusalem (14 July 2003), Nevo Legal Database (by subscription). For the argument of the fast track provisions' unconstitutionality, see generally Y. Shilo, 'Tsedek Dahuy Adif al I-Tsedek Mahir' ['Delayed Justice Is Preferable to Speedy Injustice'], 3 Alei Mishpat 317 (2003) (in Hebrew); M. Agmon-Gonen, 'I-Tlut Shiputit? Ha-lyum mi-Bifnim?' ['Judicial Independence? An Internal Threat?', 10 Ha-Mishpat 213, at 238-41 (2005) (in Hebrew). For an overview of the controversy, see Orenstein and Efron, above n. 141, Part C. highly successful. ${ }^{154}$ The fast track's procedural limitations have been given the seal of approval by the Israeli Supreme Court: according to Justice Zilbertal in a recent decision, the notion of justice is a general and complex concept integrating, among others, considerations such as the finality of proceedings and the need to allocate judicial resources reasonably; these considerations carry special weight in the context of the fast track procedure. $^{155}$

And yet, paradoxically, the fast track's much-fêted success might carry the seed of its own undoing. At first glance, and contrary to the summary procedure, the fast track is not slated to be abolished in the 2014 Draft Rules. In fact, it is the only special procedure whose retention is envisaged. ${ }^{156}$ However, the relative importance of the fast track as a specific procedural route for low(er)-value claims looks considerably diminished. ${ }^{157}$ This is due to the fact that in the Draft Rules the regular procedure has largely been amalgamated with the fast track: all proceedings are to be filed in the same manner; ${ }^{158}$ restrictions currently applying only to the fast track procedure are imposed generally on initiating counterclaims and impleaders; ${ }^{159}$ the fast track's strict discovery requirements are to be applied universally. ${ }^{160}$ Moreover, according to the Draft Rules, the court is granted broadest discretion to transfer claims not only from the fast to the regular track, but also in the opposite direction - without the consent of the parties. ${ }^{161}$ The combined result of these provisions is a considerable blurring of the line separating fast track cases from the 'standard' ones. ${ }^{162}$

The wisdom of such an approach has been questioned in recent reactions to the contemplated reform. As the critics point out, essentially erasing the procedural boundaries between small and simple claims on the one hand, and large and complex ones, on the other, does not take into account the differences inherent in the treatment of various type of cases, and could cause a general deterioration of the overall quality of judicial work (and in particular - of the standards of inquiry applied by courts),

154. See Taussig and Kleiman, above n. 131, Part B.3; Orenstein and Efron, above n. 141, Part B. The fast track was praised in the 2008 Ronen Report, which emphasised that $90 \%$ of the cases brought via the fast track route were decided during the first session of the court. The Report recommended raising the bar of fast track claims to NIS 100,000. See Ronen Report, above n. 126, at 6. The Report's recommendation was partially adopted in 2009; see above n. 131 .

155. LCA 646/14 Ashtrom Contracting Co., para. 7.

156. Draft Rules, above n. 30, at 2, 10.

157. The provisions relating to the fast track procedure has been reduced from sixteen in the current version of the RCP to just four in the Draft Rules (Rules 104-105, 107-108). See Orenstein and Efron, above n. 141, Part D.

158. Draft Rules, above n. 30, at 2,10.

159. Id., at 6. See also, Orenstein and Efron, above n. 141, Part D.1; Taussig and Kleiman, above n. 131, Part C.1, n. 69.

160. See Orenstein and Efron, above n. 141, Part D.2.

161. Draft Rules 104(B), 107. See also Taussig and Kleiman, above n. 131, Part C.1; Orenstein and Efron, above n. 141, Part D.3. Under the current regime, consent of the parties is required for a claim to be transferred to the fast track from the regular one; see above n. 140, and the accompanying text.

162. See Orenstein and Efron, above n. 141, Part E. 
especially in (more) complex cases. ${ }^{163}$ Additionally, there is concern that the proposed radical extension of the court's procedural discretion would, in effect, lead to a 'subjectivisation' of the judicial process in accordance with the personal predilections - or short-term considerations - of the trial judge. ${ }^{164}$ This, of course, would be diametrically opposed to the desired goal of harmonisation of civil procedure and would also adversely affect the parties' ability to adjust their behaviour ex ante. 165

Time will tell whether - and to what extent - the above criticisms will be able to influence the course and the outcome of the civil procedure reform in Israel. As the ultimate fate of the Draft Rules remains uncertain, so is the future place of the fast track in the Israeli system.

\section{4 'Delayed Justice' or 'Swift Injustice'? The Israeli Dilemma and Its Attempted Solutions}

\subsection{Speeding up Justice in Israel in the 2000s - Theory and Practice}

Roscoe Pound opened his famous 1906 speech by observing that ' $[\mathrm{d}]$ issatisfaction with the administration of justice is as old as law'. ${ }^{166}$ Today, these timeless words ring as true as ever. The discontent over the functioning of the justice system, and in particular over the scourge of 'slow justice' is also truly a global one. ${ }^{167}$ The public in almost every system is habitually (and increasingly) rankled over the length of time needed to obtain final judicial decisions, ${ }^{168}$ in more extreme cases the court system's inefficiency in dealing with proceedings brought before it presents a real impediment to economic growth. ${ }^{169}$ Israel is no exception to the global trend. The issue of 'speeding up' justice has been on the agenda of the legal community at least since the 1970s.

163. Taussig and Kleiman, above n. 131, Part C.1; Orenstein and Efron, above n. 141, Part D.3.

164. See Taussig and Kleiman, above n. 131, Part E.2.

165. Id.

166. See R. Pound, 'The Causes of Popular Dissatisfaction with the Administration of Justice', Address before the Annual Convention of the American Bar Association (29 August 1906), reprinted in 48 South Texas Law Review 853, at 853 (2007). See also B. Friedman, 'Dissatisfaction with the Administration of Justice: A Retrospective (and a Look Ahead)', 82 Indiana Law Journal 1193 (2007).

167. A. Klement and Z. Neeman, 'Civil Justice Reform: A Mechanism Design Framework', 164 Journal of Institutional and Theoretical Economics 52, at 53 (2008) (' $[1] f$ there is one thing common to different legal systems around the world, it is a sense of crisis, a concern that delay and litigation costs are increasing, and that the judicial system is unable to satisfy demand for its dispute resolution services').

168. For the economic analysis of excessive court delay and caseload crises, see R.A. Posner, Economic Analysis of Law, 9th edn. (2014), at 816-9.

169. Such is the tenor of a recent International Monetary Fund study on the Italian justice system. See G. Esposito, S. Lanau \& S. Pompe, 'Judicial System Reform in Italy - A Key to Growth', IMF Working Paper 14/32 (February 2014), available at: <www.imf.org/external/pubs/ft/wp/ 2014/wp1432.pdf>
On the one side of the continuous debate, the 'justice delayed is justice denied' adage is highlighted, ${ }^{170}$ while the right to have one's claim tried and resolved within a reasonable time frame is viewed as an essential part of a broader human right - that of access to justice. ${ }^{171}$ On the other side, concerns are raised over possible negative impact of a forcible reduction of delays on the rights of the parties and the quality of judicial work, as epitomised in the expression (coined by the late Israeli Supreme Court Justice S.Z. Cheshin) 'delayed justice is preferable to swift injustice'. ${ }^{172}$ The chief preoccupation is that paying too much attention to the speed of justice, and to 'efficiency' considerations in general (usually narrowly reduced, in this context, to limiting administrative costs) would cause irreparable damage to its quality by impairing the court's primary mission - that of assuring a fair process to the parties and determining the truth. ${ }^{173}$ In law-end-economics terms, these concerns broadly reflect two types of costs, the reduction of which is viewed as procedural law's economic objective: those of erroneous judicial decisions and those of operating the procedural system, ${ }^{174}$ and the tension between them. ${ }^{175}$ Additional worries are about judicial independence and the public trust in the justice system, which

170. S. Goldstein, 'Tsedek Mahir - Mabat Hashva'ati' ['Speedy Justice - A Comparative Look'], 9 Alei Mishpat 19, 19 (2011) (in Hebrew).

171. Id., at 19-23.

172. Shilo, above n. 153, at 317.

173. See Shetreet, above n. 35, at 644 ('[e]fficiency, however important it may be, is not the ultimate value. First and foremost, it has to be assured that the court system conducts a fair trial, so that speedy and efficient justice does not turn into swift injustice'); Shilo, above n. 153, at 320-7.

174. See R. Cooter and T. Ulen, Law \& Economics, 5th edn. (2008), at 417; Posner, above n. 168, at 773. Greater judicial accuracy has important social effects, as it enhances deterrence of undesired behaviour by rendering the legal consequences more certain and thereby encouraging the settlement of claims; see Ogus, above n. 136, at 238. On the value of accuracy and costs of judicial error, see generally, L. Kaplow, 'The Value of Accuracy in Adjudication: An Economic Analysis', 23 Journal of Legal Studies 307 (1994); L. Kaplow and S. Shavell, 'Accuracy in the Determination of Liability', 37 Journal of Law \& Economics 1 (1994); L. Kaplow and S. Shavell, 'Accuracy in the Assessment of Damages', 39 Journal of Law \& Economics 191 (1996).

175. According to Posner, the basic insight of economic analysis as applied to procedural law is that 'the law is engaged in making tradeoffs between the accuracy and cost of trials'; see R.A. Posner, 'An Economic Approach to the Law of Evidence', 51 Stanford Law Review 1477, at 1485 (1999). The inverse relation between the two types of costs is based on the assumption that spending more resources on the process would lead to more discovery and enable the court to achieve a more informed decision, thus reducing the probability of error; there is an optimum point where marginal benefit equals marginal cost. See $I d$. at 1481-1482; Cooter and Ulen, above n. 174, at 417; R.D. Cooter and D.L. Rubinfeld, 'Economic Analysis of Legal Disputes and Their Resolution', Journal of Economic Literature 1067, at 1087-1088 (1989). Cf., for a criticism of the assumption that the costs of the trial are a positive function of the amount of evidence, and that the effect of additional evidence on the outcome of the case will tend to decrease, R. Lempert, 'The Economic Analysis of Evidence Law: Common Sense on Stilts', 87 Virginia Law Review 1619, at 1641-1643 (2001). There is also some reason to doubt 'whether disputants value cumbersome procedural rules designed to produce accuracy as highly as do courts', as evidenced by the relative procedural simplicity of private systems of dispute resolution. See Cooter and Rubinfeld, Id. at 1088. 
might both be jeopardised, so it is feared, by overemphasis on 'efficiency'. 176

In practice, outside and beyond the theoretical debate over the court system's desirable priorities, considerable efforts to reduce case backlog have been made in Israel since 2001, bringing a certain - albeit by no means drastic - improvement. ${ }^{177}$ This modest achievement is the result of combined factors: legislative reforms such as introducing the fast track procedure, ${ }^{178}$ raising the bar of small claims, ${ }^{179}$ and empowering execution offices to directly enforce certain debts; ${ }^{180}$ a vigorous - bordering on aggressive - promotion of alternative dispute resolution, especially mediation, in order to induce parties to settle without trial; ${ }^{181}$ as well as, last but not least, the adoption by the courts of a philosophy putting greater emphasis on the allocation of limited judicial resources based on the importance of the case (with the monetary amount involved usually serving as proxy). ${ }^{182}$ The latter rationale - which also implies a partial departure from the former approach putting truth discovery above other considerations ${ }^{183}$ - lies at the heart of an organisational reform introduced in 2001-2002, in parallel with the adoption of the fast track procedure, establishing a new system of case management. The reform - which was inspired, similarly to the fast track, by the English model adopted in $1998^{184}$ - authorized the creation of case allocation (literally 'file routing') departments (mahlakot

176. See Agmon-Gonen, above n. 153, at 220-33. On the importance of 'legitimacy' of judicial decisions, see also Lempert, above n. 175, at 1651.

177. In 2003, the case backlog stood at 515, 345; see State of Israel, Courts Administration, Ma'arekhet Batei Mishpat be-Yisra'el - Du'a"h Hatsi Shnati: 1.1.08-30.06.08 [The Court System in Israel - Half-Yearly Report: 1.1.08-30.06.08] (August 2008), at 4 (in Hebrew), available at: <http://elyon1.court.gov.il/heb/haba/dochot/doc/1-6_2008.pdf>. By the end of 2013, it decreased to 440,850 cases; see Yearly Report 2013, above n. 33, at 9 . Since 2010, the balance of closed versus newly opened cases has been consistently positive. See State of Israel, Courts Administration, Ma'arekhet Batei Mishpat be-Yisra'el - Du'a"h Hatsi Shnati: 1.7.2011-31.12.2011 [The Court System in Israel - Half-Yearly Report: 1.7.2011-31.12.2011] (January 2012), at 6-7 (in Hebrew), available at: <http://elyon1.court.gov.il/heb/haba/dochot/doc/7-12 2011.pdf>; State of Israel, Courts Administration, Ha-Reshut ha-Shofetet be-Yisra'el: Du'a"h Shnati 2012 [The Judicial Authority in Israel: Yearly Report 2012] (2013), at 9 (in Hebrew), available at: <http:// elyon1.court.gov.il/heb/haba/dochot/doc/second2012.pdf>; Yearly Report 2013, above n. 33, at 9.

178. See above, Section 3.3 .

179. See above n. 83 , and the accompanying text.

180. See above, notes 101-3, and the accompanying text.

181. See generally E. Finkelstein, 'Aliyat Ma'amado shel Halikh ha-Gishur veha-She'ela ha-Hukatit' [The Rise of the Mediation Procedure and the Constitutional Question'], 8 Kiryat ha-Mishpat 403 (2009) (in Hebrew). In order to facilitate mediation, an amendment to the RCP, adopted in 2008, introduced an obligatory 'mediation meeting' between the parties in the pre-trial stage (though this has only been applied in select courts). See RCP, Rules 99A-99K; Goldstein et al., above n. 19, at 23-5.

182. See e.g. LCA $8126 / 13$ Kashdi v. State of Israel, para. 6 (26 January 2014), Nevo Legal Database (by subscription) (per Z. Zilbertal J). For a scathing criticism of this philosophy, in the context of the fast track procedure, see Shilo, above n. 153, at 341-5.

183. See above, Section 2.1.

184. See Goldstein (2011), above n. 170, at 28. le-nituv tikkim) in all courts. ${ }^{185}$ Although many aspects of the new departments are yet to be implemented in full, their goals have been clearly formulated. They include, inter alia, sorting, classification, and evaluation of cases in order to ensure that judicial time is devoted, as far as possible, only to issues requiring judicial discretion; allocation of files to a suitable track, with the aim to optimize their treatment; making preliminary approaches to parties in order to ensure honest and expeditious proceedings and, in appropriate cases, to receive their consent to referring the case to alternative dispute resolution proceedings; creation and operation of follow-up and oversight procedures over the treatment of cases in courts; advising the parties who are not represented by counsel so as to assure equal access to courts and save costs. ${ }^{186}$ Evident from these and accompanying provisions ${ }^{187}$ is the intention to take over the management of proceedings, and especially of pre-trial proceedings, from the parties and their attorneys and to transfer it to the court. ${ }^{188}$ This reflects a much more profound shift in the philosophical underpinnings of the Israeli civil procedure: from a traditional 'litigatory' model to one of 'case management', where efficiency and economy considerations reign supreme. ${ }^{189}$ And indeed, while the Supreme Court once remarked that at least one of the aims of the new case allocation system is to bridge the power and resources gap between the litigants, ${ }^{190}$ the main reason for its creation is to save public costs and to alleviate the caseload burden on the courts.

One would assume that the motivation to adopt costcutting measures - including those in the field of civil procedure - should be at its highest in times of economic distress and would tend to weaken in times of prosperity. Israeli realities do seem to conform to this almost intuitive supposition. Prima facie, a fairly straightforward link between austerity and rolling (or scaling) back the truth discovery mission of the courts, in order to promote simplicity and finality, can be established. It is indeed especially prominent in the sphere of simplified procedures. In fact, some of the more far-reaching reforms (creation of the fast track and the new case allocation mechanism, as well as the widening of the execution offices' powers of debt collection) $)^{191}$ were adopted at the time of a deep recession - bringing about in its wake harsh, across-the-board austerity cuts - traversed

185. Courts Law, Section 82A. So far, the departments have been established in the Magistrates' Courts only. See Goldstein et al., above n. 19, at 114.

186. Court Regulations (File Routing Departments in General and Labor Courts), 5762-2002, KT 6189, at 1198, at Section 3 [hereinafter: Court Regulations (File Routing Departments)]. See also Goldstein et al., above n. 19, at 114-5

187. Relating to the appointment of a 'control centre judge' and a 'legal secretary', who are to be put in charge of running the department. See Court Regulations (File Routing Departments), Sections 4, 5.

188. See Goldstein (2011), above n. 170, at 29-30.

189. On the emergence of the 'case management' system in Israel's civil procedure, see Schwartz, above n. 21, at 40-6. See also Goldstein (2011), above n. 170, at 33

190. Assurances générales de France, 60(3) PD, at 253.

191. See above notes $102,136,185$, and the accompanying text. 
by Israel in the years 2001-2003. ${ }^{192}$ Additional measures, such as raising the bar of small and fast track claims, coincided with the onset of the global financial crisis in 2008. ${ }^{193}$ Then, despite initial worries, the Israeli economy managed to cope with the consequences of the crisis quite well and emerged from it with only minimal damage. ${ }^{194}$ The relatively good economic situation, coupled with a moderate reduction of the case backlog, seem to have cooled the reformist élan somewhat. Thus, the 2008 Ronen Report recommendation to raise the bar of fast track claims to NIS $100,000^{195}$ has not been implemented, and other cost-saving procedural reforms have been eventually abandoned. ${ }^{196}$

The pattern described above looks too consistent to be a mere coincidence. And yet, despite the apparent connection between the state of the Israeli economy and the incidence of procedural reform, some caveats are in order. First, the pattern is seemingly broken by the 2015 amendment increasing the maximum sum of claims amenable to the 'direct execution' track, ${ }^{197}$ which was legislated not during a period of crisis, but rather of stable, albeit reduced, economic growth ${ }^{198}$ (one should bear in mind, however, the rather limited scope of the change introduced). ${ }^{199}$ Second, the straightforward rhetoric of (budgetary) austerity is virtually absent from the available published legislative debates on the adopted amendments. The terms used and the themes referred to are 'economy', 'efficiency', 200 as well as reducing

192. See above n. 8, and the accompanying text.

193. See above notes 83,137 , and the accompanying text.

194. See above n. 5, and the accompanying text.

195. See above n. 154.

196. See Shetreet, above n. 35, at 624-5.

197. See above n. 102, and the accompanying text.

198. See above n. 6 .

199. Raising the bar from NIS 50,000 to NIS 75,000 would enable the transfer of about 6,000 claims from the courts to the Execution Offices (out of over 700,000 cases filed yearly). See The Knesset, Constitution, Law and Justice Committee, Protocol no. 20, above n. 115. It should be noted that the 2015 amendment also dealt with the technical aspects of improving notice on the debtor. See Id.; Execution Law Bill (Amendment No. 46), above n. 132. The amendment was voted unanimously both in the Committee and in the Knesset plenum; on the vote, see the Knesset website at: <http://main.knesset.gov.il/Activity/Legislation/ Laws/Pages/LawSecondary. aspx?lawitemid=566316>.

200. See e.g. the explanatory notes to the 2002 Execution Law Bill (Amendment No. 25), above n. 121, introducing the 'direct execution' track (the proposal's goal is 'to advance economy and efficiency'), and the Committee debate on this measure, see The Knesset, Constitution, Law and Justice Committee, Protocol no. 429, above n. 115 (Committee Chairmen O. Pines-Paz stressing that the amendment would 'save the Government's expenses'). See also the debates on increasing the upper limit of small claims, The Knesset, Constitution, Law and Justice Committee, Protocol no. 598, above n. 84 (highlighting the proposal's contribution to reducing costs) and of claims in the 'direct execution' track, The Knesset, Constitution, Law and Justice Committee, Protocol no. 20, above n. 115 ('efficiency' mentioned among the proposed rationales of the proposed change). The 'economy of time and resources', both to the parties to the litigation and to the court system, is prominently featured in the explanatory notes (by the Israeli Ministry of Justice) to the draft introducing the fast track procedure to the RCP in 2001; published in Cohen and Klein, above n. 136, Appendix B, at 64. the caseload burden. ${ }^{201}$ Third, and probably most importantly, it is evident that the reforms introduced in times of economic difficulty - especially the more radical ones - require lengthy preparatory work which does not temporarily overlap with (cyclic) economic downturns. Such is prominently the case of the 2001 amendment to the RCP creating the fast track, which closely follows the 1998 'Woolf Reform' in England, but has even earlier local precursors. ${ }^{202}$

In light of the above qualifications, what is left, if at all, of the purported link between 'austerity' and the measures to simplify Israel's civil procedure? An argument can be made that the link still exists, although it is of a more indirect and less mechanical nature. In this context, economic woes can be seen as creating a general atmosphere propitious to actually go through with reforms which might have fizzled out (or would have been postponed) in a climate of relative prosperity. 'Austerity', thus, becomes both an impetus and an ideological 'cover' for procedural simplification, which influences all the relevant parties: the reform's stakeholders, the legislators, and the general public. ${ }^{203}$ As the atmosphere created by economic crisis dissipates, on the other hand, the impetus and the ideology's hold over hearts and minds weaken, and contrary considerations come to the fore. While this general thesis certainly requires additional research based on substantial empirical evidence may be required (not least as to its precise scope), it can be buttressed somewhat by the recent and ongoing - Israeli experience with the far-reaching proposal to simplify civil procedure incarnated in the new Draft Rules of Civil Procedure. The salient provisions of the Draft and the debate over it are sketched out below.

\subsection{A New Beginning or a Dead End? The 2014 Draft Rules of Civil Procedure}

In the last days of 2014, the Draft Rules, drawn up by a team headed by the former Courts Administrator, Judge (ret.) Moshe Gal, were published by the Israeli Justice Ministry. The Draft's aspirations are far-reaching: it purports to replace the currently valid 1984 RCP with a modernized and 'user-friendly' civil procedure code. The radicality of the proposed reform is evident in the drastic slimming down of the black-letter substance from over 700 rules in the current version of the RCP to just $176 .^{204}$ This fact alone shows that the Draft's core aim is that of overall simplification and streamlining of civil procedure in Israel. While a detailed analysis of

201. See in this vein e.g. The Knesset, Constitution, Law and Justice Committee, Protocol no. 429, above n. 115; The Knesset, Constitution, Law and Justice Committee, Protocol no. 598, above n. 84; The Knesset, Constitution, Law and Justice Committee, Protocol no. 20, above n. 115.

202. See above, Section 3.3. On the historical and preparative background of the 2001 reform in Israel, dating back to the mid-1990s and even to the late 1980s, see Cohen and Klein, above n. 136, at 7-9, 64-6.

203. On the 'ideology of austerity', see generally M. Blyth, 'Austerity as Ideology: A Reply to My Critics', 11 Comparative European Politics 737 (2013)

204. Draft Rules, above n. 30, at 2 . 
specific substantive provisions of the Draft Rules is outside the scope of this article, it is clear that their main thrust is to unify all proceedings largely 'under one roof ${ }^{205}$ Even though the proposed unification is incomplete (the small claims are unaffected, summary procedure survives in part, and the fast track is retained in principle), ${ }^{206}$ the effect of the reform on both 'regular' and simplified procedures is easily discernible: the two are being 'merged', with the 'standard' civil procedure now looking more like a 'simplified' one itself. This 'submerging' of the simplified procedures by 'regular' procedure, while certainly not rendering the former (completely) redundant, does significantly reduce their prominence.

What is even more important, however, is the Draft's underlying philosophy. It marks a departure from the formerly prevalent approach of procedural flexibility towards more rigidity. ${ }^{207}$ It seals the process of transformation of the Israeli system from (an originally adversarial, later more inquisitorial) 'procedure' into 'case management', focused on 'efficiency'. ${ }^{208}$ As a matter of fact, although the goals of 'efficiency' and 'swift justice' are not included in the Draft Rules themselves (which only specifically refer, in the introductory chapter devoted to 'Basic Principles', to 'resolution [of disputes] within a reasonable time'), ${ }^{209}$ they are peppered through the Draft's explanatory notes. ${ }^{210}$ In the end result, the delicate pre-existing balance between 'economy' (meaning, in this context, a speedy resolution of cases) and 'quality' (meaning a thorough investigation of the evidence and of the parties' arguments) ${ }^{211}$ is tilted drastically in the Draft in favour of 'economy'. ${ }^{212}$ Given all this, it is not a major exaggeration to say that the Draft Rules, if adopted, would represent a paradigmatic, almost tectonic shift in Israeli civil procedure law.

The elaboration of the Draft Rules occurred completely under the radar, and their publication was not preceded

205. Id. See also Taussig and Kleiman, above n. 131, Parts A, C.1.

206. See above, the text accompanying notes 84 , at 125-7, 150-1.

207. The Draft puts great emphasis on enforcing the prescribed delays as well as on reducing the scope of the parties' written pleadings; violations are to be sanctioned administratively by the court's 'legal secretary' who is authorised to deny the filing of documents. See Draft Rules, above n. 30, at 2-3; Rule 35. Moreover, the Draft introduces (in its Part B, Chapter B), the 'Pre-Action Protocol', imposing rather burdensome obligations on the claimants prior to initiating the proceedings; these obligations create significant 'sunk costs'. See Id., at 3; I. Rosen-Zvi, 'Reforma Meyuteret u-Mezika' ['A Superfluous and Harmful Reform'], 28 Orekh ha-Din 68, 71 (2015) (in Hebrew). On the tendency of the Israeli jurisprudence towards a flexible interpretation of procedural rules, see above, Section 2.1.

208. See Schwartz, above n. 21, at 40-6

209. Draft Rules, Rule 2.

210. See Draft Rules, above n. 30, at 1, 2, 4, 9, 11

211. According to the terminology coined by Adrian Zuckerman; see A.A.S. Zuckerman, 'Quality and Economy in Civil Procedure: The Case for Commuting Correct Judgments for Timely Judgments', 14 Oxford Journal of Legal Studies 353 (1994). See also Shetreet, above n. 35, at 623-4 (describing the tension between 'efficiency' and 'fair process' as inherent in the administration of justice).

212. See Orenstein and Efron, above n. 135, Part D. by public debate. ${ }^{213}$ The reactions to the Draft from both the academic and the practicing lawyer community have been predominantly negative, ${ }^{214}$ in fact, it seems the only active support for the Draft Rules has come from the 'Gal team' members themselves. ${ }^{215}$ The criticisms levelled against the Draft are varied, ${ }^{216}$ but behind most of them one general concern can easily be identified: that the proposed reform goes way too far in its simplification and homogenisation drive. ${ }^{217}$ The general, overriding criticism points out to the limits of (over-)simplification: the Draft is based on a (naive) assumption that 'simple rules will turn the reality into a simple one'; 218 however, when 'simple' rules come into contact with a complex reality, elaborate interpretative adjustments are inevitably required. ${ }^{219}$ The reform is thus liable to generate more problems than it purports to solve, while upsetting the balancing act between the various goals and values of civil procedure, created and maintained by the legislator and the courts over the years. $^{220}$ Ultimately, and to use Adrian Zuckerman's terminology, the Draft Rules, instead of 'rationing procedure', end up rationing access to justice. ${ }^{221}$ Rather unsurprisingly, this attack on the simplification drive of the Draft Rules is aided by recent criticisms of the achievements of the Woolf reform. ${ }^{222}$

In light of the above, what does the future hold in store for the Draft Rules? According to a Talmudic saying,

213. See I. Baum, 'Kakh Tira'e ha-Reforma she-Teshane et Kol ha-Tvi'ot haEzrahiyot be-Yisra'el' ['This Is What the Reform That Will Change All Civil Proceedings in Israel Will Look Like'], The Marker, 26 November 2014, available at: <www.themarker.com/law/1.2495731> (in Hebrew).

214. See Rosen-Zvi, above n. 207; R. Liba, 'Hahlafat Takanot Seder ha-Din ha-Ezrahi me-ha-Yesod Alula Ligrom Davka le-Omes' ['Completely Replacing the Rules of Civil Procedure Is Liable to Cause More Burden'] Globes, 26 January 2015, available at: <www.globes.co.il/news/article. aspx?did=1001003736> (in Hebrew); I. Baum, 'Ha-Hatsa'a le-Reforma be-Takanot Seder ha-Din ha-Ezrahi Haya ve-Sofeget Be'itot' ['The Proposed Reform of the Rules of Civil Procedure Is Alive and Getting Kicked'], The Marker, 13 April 2015, available at: <www.themarker. com/law/1.2612179> (in Hebrew); S. Kalfon, 'Lishkat Oha'd Yotset Neged ha-Reforma be-Takanot Seder ha-Din ha-Ezrahi' ['The Bar Association Comes out Against the Reform of the Civil Procedure Rules'], Globes, 15 July 2015, available at: <www.globes.co.il/news/article. aspx?did=1001053287> (in Hebrew)

215. See Baum, above n. 214.

216. One specific criticism concerns the (partial) abolition of existing special and/or simplified tracks (such as the summary procedure). It is argued that these are, in reality, considerably more successful than the standard procedure in achieving the goal of 'speedy justice'. See above notes 130-131, and the accompanying text.

217. See, among others, Orenstein and Efron, above n. 141, Part E; Taussig and Kleiman, above n. 131, Parts A, F.

218. Rosen-Zvi, above n. 207, at 70.

219. Id.

220. See Liba, above n. 214; Baum, above n. 214; Rosen-Zvi, above n. 207, at 69-70.

221. See Baum, above n. 214; Kalfon, above n. 214; Rosen-Zvi, above n. 207, at 71. On the concept of 'rationing procedure', see A.A.S. Zuckerman, 'A Reform of Civil Procedure: Rationing Procedure Rather Than Access to Justice', 22 Journal of Law and Society 155 (1995).

222. See e.g. H. Genn, 'What Is Civil Justice For? Reform, ADR and Access to Justice', 24 Yale Journal of Law and the Humanities 397 (2013). Professor Genn was one of the speakers at the Tel-Aviv University conference where the 2014 Draft was severely criticised. See Baum, above n. 214. 
prophecy has been given to fools and children; ${ }^{223}$ this is all the more true with regard to pending (secondary) legislation. Nevertheless, drawing on past Israeli experience, the current juncture does not look particularly propitious for a major break with the accepted status quo (which has remained unchanged in its foundations since the time of the British Mandate in the 1930s, and has only been tampered with in a piecemeal fashion and rather sparingly). The recent procedural reforms sacrificing 'quality' on the altar of 'efficiency' (which, as shown, have mostly coincided with periods of economic downturn), were either mostly uncontroversial (as in the case of the changes concerning the small claims and the summary tracks $)^{224}$ or faced only limited and brief criticism (as in the case of the fast track procedure). ${ }^{225}$ The determined opposition encountered by the new Draft is of a totally different nature. It shows that, notwithstanding the continuing dissatisfaction with the justice system's performance, and especially with its slowness, the force of cost-saving 'efficiency' arguments has weakened considerably; ${ }^{226}$ and that a crisis mentality favouring drastic reform is largely absent both in the legal profession and among the political decision-makers. It is thus understandable that one of the chief criticisms raised against the reform put forward in the Draft Rules is that it is 'superfluous'. ${ }^{227}$ This 'don't fix it if it isn't broken' logic seems to be carrying the day at this point. ${ }^{228}$ Time will tell whether this conservative attitude will continue to prevail in the middle term.

\section{Concluding Remarks}

The recent global financial and economic crisis has highlighted that civil procedure is not exempt from austerity considerations. Although the last crisis barely made a dent in the Israeli economy, concerns over the perceived inefficiency of the existing civil procedure have dominated the Israeli public debate for years. These concerns centre largely on the excessive length of proceedings; 'slow justice' with its attendant inefficiencies and potential injustices (which are exacerbated by high litigation costs) is widely perceived as the bane of the current system. Over the years, various simplified procedures have been created and developed by the legislator for certain types of claims, providing alternatives - and complements - to the regular track. These procedures, overviewed in detail in the present article, have

223. Babylonian Talmud, Baba Bathra, 12b.

224. See above, Sections 3.1 and 3.2.

225. See above, notes 153-154, and the accompanying text.

226. For Israel's above-average economic performance during the last few years, see above notes 5 and 6 , and the accompanying text.

227. See the title of the article by Rosen-Zvi, above n. 207.

228. An additional factor potentially influencing the Draft's future prospects is that two key supporters of civil procedure reform have left their positions: Justice Minister Tsipi Livni (who was dismissed from the Government in 2013) and Chief Justice Asher Grunis (who retired in early 2015). See Baum, above n. 214. The position of the current Justice Minister, Ayelet Shaked, who represents a different political party and holds pronouncedly anti-activist views, is not (yet) publicly known. served an invaluable role in alleviating the overall litigation burden of Israeli courts. They also seem to have successfully charted the middle ground between the two opposing poles: one of 'economy', concerning itself with the limited resources of the justice system and the need for speedy and final resolution of disputes, and the other one, that of 'quality', emphasising the courts' primary mission of truth discovery as a pre-requisite to arriving at a 'just' solution.

Some measure of the success of simplified procedures in Israel can be seen in the substantial widening of their scope in the years 2000, with little or no opposition. This enlargement of the simplified procedures' relative weight within the Israeli system (including the creation of a new 'fast track' for low-value claims) was mostly greeted with approval on the part of both the members of the legal profession and the general public. However, the ball did not stop there. In fact, the simplified procedures' accomplishments have carried over to the regular procedure, and the policy makers appear to have come close to being carried away by them. The recent reform proposal by the Justice Ministry, embodied in the 2014 Draft Rules, represents a transfusion of norms and principles derived from simplified procedures into the 'standard' civil procedure. As shown in the article, the Draft blurs the boundaries between the 'simplified' and the 'regular' procedures to a great extent. Contrary to previous reforms, this blurring of the lines has elicited largely negative reactions and even a sort of a backlash, putting a question mark over the reform's prospects both in the short and the middle term.

The vigorous opposition to the proposed Draft Rules symbolises the limits of the attempts to further simplify civil procedure in the name of 'efficiency' and 'speeding up justice', beyond lower-value and prima facie 'simple' claims. It also illustrates the connection between austerity and civil procedure reform: simplification of procedure, sacrificing 'quality' on the altar of efficiency, are accepted and even hailed by the public in times of real or perceived crisis; with good economic performance, concerns for assuring truth discovery - which requires a comprehensive examination of evidence and the parties' arguments - come to the fore. While more research on the connection between austerity and civil procedure is needed, the Israeli example does show that attempts to tilt the balance toward (ever more) 'efficiency' in civil procedure outside austerity/crisis situations are viewed with suspicion, as unjustified endeavours to 'cut corners'. 